\title{
Agro-Food Byproducts as a New Source of Natural Food Additives
}

\author{
Margarida Faustino, Mariana Veiga $\mathbb{D}^{D}$, Pedro Sousa, Eduardo M. Costa $\mathbb{D}$, Sara Silva and \\ Manuela Pintado*
}

CBQF-Centro de Biotecnologia e Química Fina-Laboratório Associado, Escola Superior de Biotecnologia, Universidade Católica Portuguesa, Rua Arquiteto Lobão Vital 172, 4200-374 Porto, Portugal;

afaustino@porto.ucp.pt (M.F.); mveiga@porto.ucp.pt (M.V.); pedro.miguel.c.s@hotmail.com (P.S.);

emcosta@porto.ucp.pt (E.M.C.); snsilva@porto.cup.pt (S.S.)

* Correspondence: mpintado@porto.ucp.pt; Tel.: +351-225-580-097

Academic Editors: Lillian Barros and Isabel C.F.R. Ferreira

Received: 4 February 2019; Accepted: 12 March 2019; Published: 18 March 2019

check for updates

\begin{abstract}
Nowadays, the agro-food industry generates high amounts of byproducts that may possess added value compounds with high functionality and/or bioactivity. Additionally, consumers' demand for healthier foodstuffs has increased over the last years, and thus the food industry has strived to answer this challenge. Byproducts are generally secondary products derived from primary agro-food production processes and represent an interesting and cheaper source of potentially functional ingredients, such as peptides, carotenoids, and phenolic compounds, thus promoting a circular economy concept. The existing body of work has shown that byproducts and their extracts may be successfully incorporated into foodstuffs, for instance, phenolic compounds from eggplant can be potentially used as a mulfitunctional food additive with antimicrobial, antioxidant, and food colorant properties. As such, the aim of this review is to provide insights into byproducts and their potential as new sources of foodstuffs additives.
\end{abstract}

Keywords: byproducts; food additives; antimicrobial; antioxidant; colorants; texturizing agents; foaming capacity and emulsifiers

\section{Introduction}

Food functionalization is an ever-increasing market that requires new bioactive ingredients that can be used by the food industry for the development of innovative functional products with scientifically sustained claims. In this regard, much attention has been paid in recent years to natural compounds and their associated bioactivities. However, natural sources are finite, and new alternatives have to be sought to sustain the ever-growing needs for ingredients and additives of the food industry [1,2].

The European Union (EU) action plan for the circular economy to reduce food waste includes a strategic approach based on the reduction, reuse, recovery, and recycling of materials and energy, enhancing the value and consequently the useful life of products, materials, and resources in the economy. The reuse of agro-industrial byproducts can represent a renewable source for some already in use food additives or even originate new added-value ingredients with functional compounds and properties, which will benefit the entire food system [3]. For instance, byproducts contain polysaccharides, organic acids, proteins, and other compounds, which, at no additional production cost and at a reduced industrial cost, make them a rich source of natural compounds that can potentially be applied in the food industry as food additives sources (summarized in Table 1) [4].

Furthermore, these natural compounds may also be regarded as nutraceutical ingredients or complements, allowing for the development of products with enhanced nutritional value, potential health benefits, longer shelf-life, as well as a good sensory profile [5-7]. 
Table 1. Potential applications of agro-food byproducts compounds.

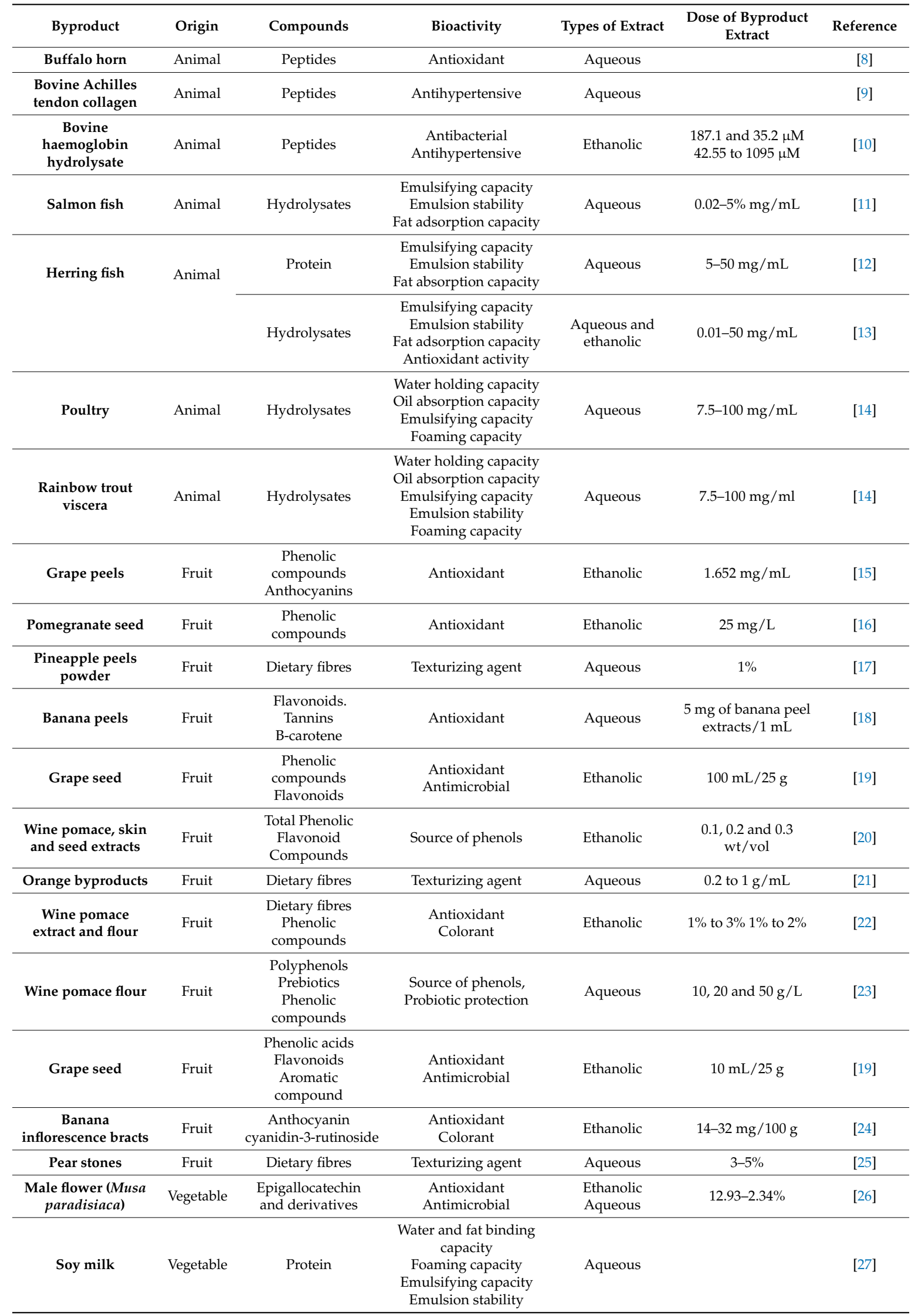


Table 1. Cont

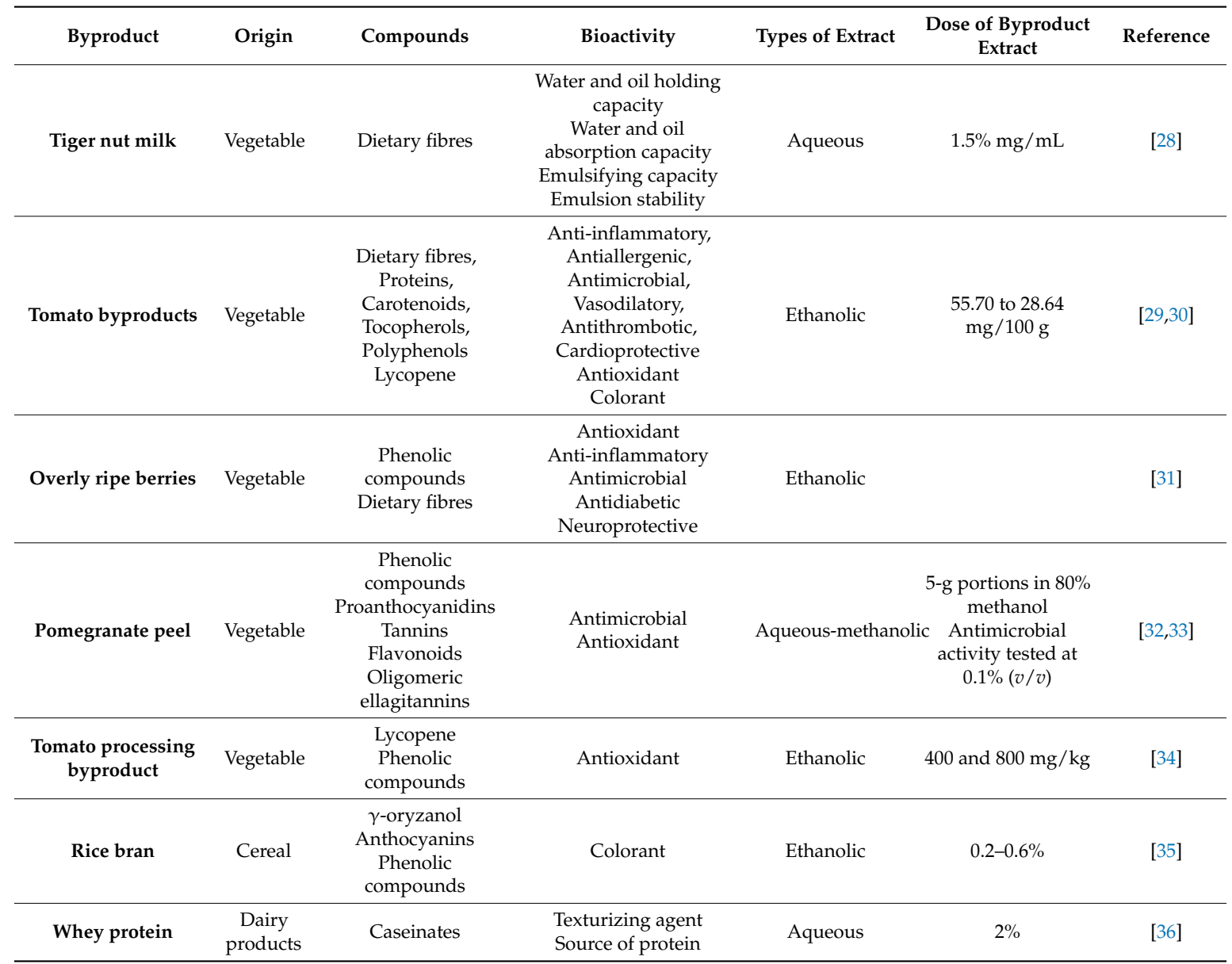

Taking this into account, this review aims to provide a broader look into the potential use of byproducts as new sources of food additives (already in use or potential new ones) to be used by the industry.

\section{Consumer Perspectives}

In the 1960s, the E number system was introduced to assure consumers that the additives included into their foodstuffs were safe for consumption. However, the use of this code made some consumers reticent in regard to these compounds with false allegations (on their lack of safety) being made in some publications [37-39]. Moreover, with the increase in life expectancy, concerns grew in regard to overall life quality. This, coupled with the widespread link between diet and health, made consumers particularly aware of the foodstuffs they ingested and increased the demand for healthier solutions. One trend associated with this shift in perception is "clean labels", i.e., products that are perceived as "natural", such as "free-range", "less processed", "organic", or "biological" foods $[39,40]$. Overall, this means that not adding additives has become a differentiating factor for food products, and consequently that the industry has become more interested in new solutions that, while exerting the same technological effect as traditional additives, have no negative perception. Agro-food byproducts present an interesting source of bioactive and technologically relevant compounds that, given their low commercial value, pose as a relevant potential source of new natural additives [41-44].

\section{Applicable Legislation}

Food additives have an essential role in the current industry and consumption habits, as they not only make food products more appealing, but they increase their stability and inherent safety. Overall, 
food additives may be defined as compounds/extracts that are added to a food product in order to accomplish a specific technological goal but are not ingested as a food product themselves. According to the European Food Safety Agency (EFSA), an additive must not pose a safety concern for the consumers health (when ingested) while fulfilling a specific technological need that cannot be satisfied through other reasonable means. Examples of these needs are the enhancement of the sensory quality, the fulfillment of specific dietary needs, or the ease of production, packaging, transport, and/or storage of food products [45]. Overall in the EU, the use of additives (non-enzymatic) is regulated by European Commission (EC) No 1333/2008 with the additives, the list of allowed additives, and subsequent limitations always dependent on the appearance of new evidence regarding their safety. In this legislation, the different groups are defined (Table 2) along with rules on how an additive must be referred to in a product (e.g., the information must be present in the label with the compounds referred to either by their name or their E-number and by the function they play in the final product). Moreover, food additives must follow specific purity criteria that are described in three different directives: Directive 2008/60/EC for sweeteners; Directive 2008/128/EC for colors; and Directive 2008/84/EC for other additives [46-48]. After the inclusion of the list of approved additives and food carriers (and the conditions associated with their use) into Regulation (EC) No 1333/2008, a revision of the purity criteria of food additives was undertaken, resulting in a new regulation, Regulation (EU) No 231/2012, that repealed the previous directives for sweeteners, colors, and other additives [45,48-50].

Table 2. Types of food additives and their functions as described by European Food Safety Agency (EFSA) in Regulation (EC) No 1333/2008.

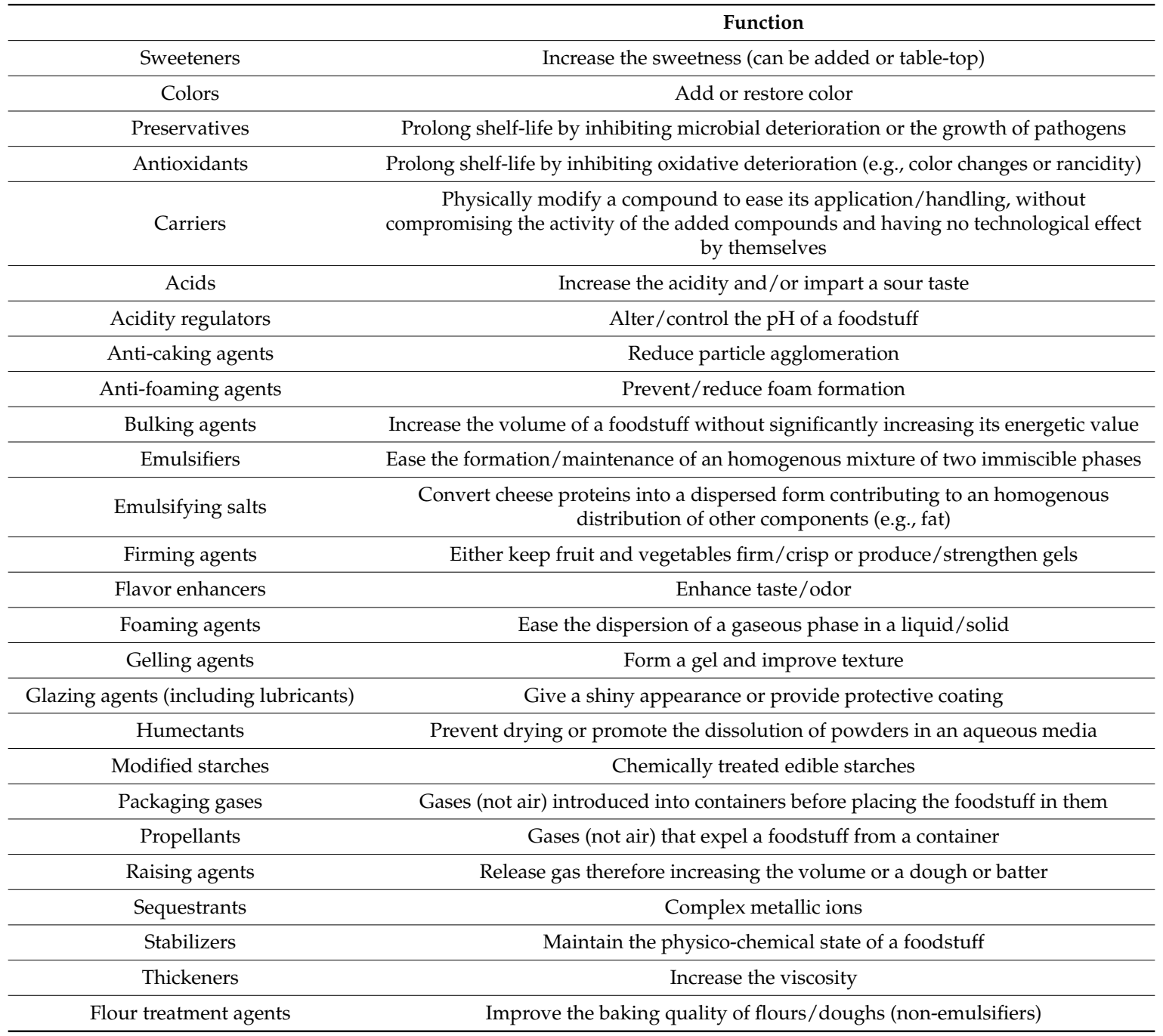


Some of the additives currently allowed under the scope of Regulation (EC) No 133/2008 may be found in agro-food byproducts. Namely, anthocyanins (E163) may be found in grape/winemaking byproducts, chlorophylls (E140) may be found in almost all green leaf vegetable byproducts or mango peels along with all green leaf wastes that result from pruning during agricultural production, and lycopene (E160d) can be found in tomato wastes [51-57]. There is a consensus that as long as the additive compound/molecule is already part of the list of authorized compounds, it can be used [58]. However, if the production process is varied significantly (by using a significantly different raw matter or using new production procedures), the "new" additive must be evaluated again by EFSA. This means that the focus given to the development of new and more efficient green technologies to attain additives from agro-food byproducts may result in potential new additives that must be subjected to a new evaluation in order to ensure their safety. This path starts with a thorough safety (short and long term) evaluation of any potential metabolic, genotoxic, reproductive, and chronic or carcinogenic side effects [59]. Following this, it is possible to define a no observable effect level (NOEL) and then an allowable/acceptable daily intake (ADI). Once all the relevant information is gathered, EFSA or other similar organizations (like the Food and Drug Administration-FDA) can be petitioned to validate the introduction of the additive through an amendment of the legislation in order to add the substance to the list of authorized food additives. If this authorization is granted, the additive will be eligible to be used on the market under direct supervision of the agency that granted the permission $[49,59,60]$. In the EU, the submission of a potential new additive for validation must start with an application submitted to the EC, who will verify it. If valid, EFSA must then give an opinion within a timeframe of nine months, a period that may be extended if further information is required from whoever submitted the application (for risk management purposes, EC may also require further elucidation). If EFSA gives a positive opinion, EC has nine months to submit a regulatory draft aimed at the inclusion of the substance in the allowed additives list, whose approval is dependent on the votes of member states. If approved, as with all decisions of the EU, it must then pass a three month long period of scrutiny. Overall, this process is very long and, in the new era of circular economy where food byproducts valorization is of the upmost importance, legislation approaches should be reanalyzed to facilitate and speed up the process of new additives approval while still guaranteeing the safety of the final additive $[49,61]$.

\section{Preservatives}

Microbiological processes can adversely affect the quality of food, leading to its spoilage. For this to occur, conditions that favor the growth and development of spoilage microorganisms must be met, such as bioavailable nutrients, favorable water activity, adequate $\mathrm{pH}$ value, presence/absence of oxygen, and redox potential [62]. The term "food spoilage" is only applied if the changes in the foodstuffs due to the microorganisms' potentially harmful metabolic products become recognizable, thus making the product unsafe for consumption and augmenting the risk of foodborne illness [62-65]. However, not all microbiological change in food is considered harmful (for example, fermentation of grape juice in order to produce wine) [66].

Taking this into account, preservatives are widely used in the food industry in order to prevent microbial contaminations, demonstrating a significant impact upon a product's shelf-life as well as food safety [58,66-68]. There are different antimicrobial compounds that can potentially be used as preservatives ranging from enzymes, bacteriocins, fungicides, and salts to essential oils and other components, some of which may be found agro-food byproducts [7,69-76]. The use of natural compounds to replace traditional additives is an emerging trend that has been driven by the consumer's preferences for "clean labels", with the scientific community striving to provide natural alternatives, some of which may be attained from agro-food byproducts (e.g., phenolic compounds) [7,44,77]. Nitrates (E240-E259) and nitrites (E249-E250) are the most commonly used preservatives in foodstuffs. Both have been associated with the formation of nitrosamine (a carcinogenic compound responsible for the development of gastric and other types of cancer). Therefore, actions have been taken to 
reduce their intake [the current daily intake for nitrates is 3.7 milligrams per kilogram of body weight ( $\mathrm{mg} / \mathrm{kg}$ bw/day), while for nitrites it was re-established to $0.07 \mathrm{mg} / \mathrm{kg}$ bw/day] [78-80]. However, EFSA determined that there was insufficient evidence to ban the use of nitrates and nitrites as food additives due to health concerns, particularly with them being the only additives capable of exerting antimicrobial activity against Clostridium botulinum and preventing botulinic toxin production/accumulation [81].

Agro-food byproducts, particularly fruit peels and seeds, have been regarded as a potential source of preservatives with several reports reporting on the potential antimicrobial activity of different fruit and vegetable byproduct extracts, which could potentially be translated into an industrial application if the appropriate regulatory body gives a positive opinion [7,41,67,82]. For instance, Gul and Bakht [83] reported how an ethanolic turmeric extract possessed antibacterial activity against Escherichia coli and Staphylococcus aureus, an effect that has been attributed to its phenolic content [84-86]. Additionally, turmeric oil, a byproduct from curcumin manufacture, has also been described as possessing antibacterial and antifungal activity [86-88]. Berries are fruits with high phenolic content, particularly anthocyanins. While by themselves they possess an interesting commercial value, if the fruits fall from the bushes (overly ripe berries), they will not be commercialized [89-91]. However, they remain a phenolic rich fruit that can be used as a source of potential antimicrobial additives. For instance, blueberry and cranberry anthocyanin-rich extracts have been reported as possessing vast antimicrobial activity and could potentially be exploited as new natural food additives [92-97]. Olive leaves are also a good source of phenolic compounds and have been reported as possessing some antimicrobial activity against Bacillus cereus, E. coli, S. aureus, and some fungi such as Candida albicans and Cryptococcus neoformans [98-101]. Wang, et al. [102] reported how the addition of green tea polyphenols (mainly constituted by catechins) and tocopherol to dry-cured bacon resulted in significantly lower Enterobacteriaceae content. Green tea and black tea wastes have been studied for their potential nutritive, antimicrobial, and antioxidant values due to their high tannin and catechin content $[103,104]$.

Wine pomace, a well-known byproduct, also showcases some potential as a new source of antimicrobial food additives, as its activity has also been associated with its high phenolic content and anthocyanins in particular [22,105]. Pomegranate peel extracts, reported to be natural inhibitors of food-borne pathogens such as Listeria monocytogenes, E. coli, and Yersinia enterocolitica, have been added to poultry products with the results showing good antimicrobial activity against $S$. aureus and $B$. cereus and permitting the increase of shelf-life by two weeks [32,33,106-109]. Avocado, a tropical fruit, has also been described as possessing a relevant antimicrobial activity, with several reports focusing on the biological activity of its peel and seed [110,111]. For instance, Calderón-Oliver et al. [112] reported how a nisin (an antimicrobial peptide) avocado peel mixture resulted in an enhancement of nisin's antimicrobial activity against food-borne pathogens such as Listeria sp. Overall, the reported results favor the use of natural byproduct extracts as potential new preservatives at an industrial level, helping to reduce costs and environmental impact, although the leap to an industrial setting is limited by a lack of regulatory framework for their use.

Currently, the only animal derived antimicrobial additive used in the EU and United States (US) is lysozyme (E1105). Lysozyme originates from eggs, and while it is mainly used in cheese conservation, studies concerning eggs, milk, and beef have been carried out. However, it does not exert any action against yeasts or fungi [113-115].

\section{Antioxidant Additives}

Oxidation is a not a process exclusive to the human body. It occurs in every living organism and biological system, such as food products. Food oxidation may result in altered flavor, color, nutritional value, and texture, as well as create toxic compounds $[82,116,117]$. As such, antioxidant compounds are one of the most important conservation technologies used by the food industry with their main function being the prevention of oxidative induced degradation of foods, therefore allowing for extended shelf 
times $[82,117,118]$. These additives help stabilize lipids (avoiding lipidic peroxidation) as well as other compounds and can neutralize free radicals, avoiding a cascade of oxidative reactions. [117,119].

As previously mentioned, due to a shift in consumer preferences, in recent years there has been an increase in the demand for more natural (i.e., with less additives) food products [120]. As such, there have been studies comparing synthetic and natural antioxidants with results showing that natural phenolic antioxidants are capable of inhibiting oxidation and toxin formation, meaning that they present an interesting natural alternative to the traditionally used antioxidant additives $[117,121]$. Butylated hydroxy anisole (BHA), butylated hydroxytoluene, ethoxyquin, tert-butylhydroquinone, and propyl gallate are the most common synthetic antioxidants used in foods. Reports on their potential health impact are divided [121-124].

Since plants are one of the main sources of antioxidants compounds, agricultural byproducts are among the most relevant potential sources of natural antioxidants that could be exploited for product quality preservation. Phenolic compounds, besides being associated with antimicrobial activity, are known for their high antioxidant capacity. They are ubiquitous to plants and therefore present one interesting class of antioxidant compounds to be exploited, although other compounds with a strong antioxidant capacity can also be found, such as some vitamins (vitamin C, E, and A), bioactive peptides, polysaccharides, some minerals, and enzymes. Any byproduct with a high content of any of these compounds may be regarded as a possible source of new antioxidant food additives, e.g., overly ripe berries, or citric and exotic fruits, peels, and seeds $[77,116,121,125]$. Meat byproducts (including blood, bones, meat trimmings, and viscera) can result in protein hydrolysates with a relevant bioactivity, namely antioxidant bioactive peptides $[126,127]$. Onion byproducts (namely onion peels and stems) have been regarded as potential food additives due to their antioxidant and anti-browning properties [128]. Larrosa et al. [129] reported that adding an artichoke byproduct extract (namely artichoke blanching waters) to a tomato juice resulted in higher antioxidant activity (measured by the $\mathrm{DPPH}^{\bullet}$ and $\mathrm{ABTS}^{\bullet+}$ methods) and consequently a longer shelf life for this product. Similarly, eggplant aqueous acetone extracts have also been studied, with reports describing a high antioxidant potential of its peels (evaluated by FRAP and TEAC) likely due to its rich anthocyanin content [130]. Mango byproducts are an example of a vastly studied tropical fruit with a high antioxidant capacity and a wide range of potential applications [54,131]. An example is the inclusion of mango peel powder in macaroni and bakery products (such as biscuits) to provide some added functional value as well as function as a natural antioxidant (as the supplemented products exhibit a higher capacity to quench $\left.\mathrm{DPPH}^{\bullet}\right)[54,132,133]$.

The potential for the use of natural alternatives to antioxidant additives has been supported by the work of Caleja, Barros, Antonio, Oliveira, and Ferreira [121], who reported no significant differences between the use of natural extracts (chamomile and fennel) and a synthetic (BHA) antioxidant additive in biscuits, with no significant changes in color or nutritional value observed after 60 days of storage. Similarly, there have been reports on the successful addition of natural antioxidant extracts to bakery, dairy, and meat products, which also confer some added functionality to the foodstuffs [79,121,134-137]. Overall, byproducts of industrial fruit processing consist mainly of seeds, peels, and unused flesh. Some of these residues have been reported as possessing a higher concentration of bioactive compounds than the used fruit flesh $[108,111,132,138-140]$. Furthermore, the antioxidant compounds of natural origin, when attained using adequate solvents, are considered as generally recognized as safe (GRAS). Moreover, some of the antioxidant compounds naturally found in these byproducts are already approved for use as antioxidant additives and possess an E number, namely ascorbic acid (E300), tocopherol (E306), and $\beta$-carotene (E160a) [68,102,113].

\section{Food Colorants}

Although the flavor and nutritional value tend to be the most studied and appreciated components of a food product, its appearance is also an important sensory aspect [141,142]. Colorants are food additives used to impart color to foodstuffs to make them look more appetizing and/or help 
compensate color loss due to exposure to natural elements (light, air, temperature, etc.) [143,144]. Color plays an important role in the consumer's emotional reaction and acceptance of food. Color is appreciated both for its aesthetic and quality indicator role, as an adequate color is frequently used for quality assessment due to its association with flavor, nutritional value, and food safety [145]. Color provides visual suggestions to flavor identification and taste thresholds, influencing food preference, food acceptability, and ultimately, food choice [146]. Current market trends include the substitution of synthetic colorants for natural compounds found in certain foodstuffs (such as fruits) or in food byproducts, a trend that is reinforced by studies regarding possible detrimental effects of synthetic colorant usage in foods [142,144]. Most commercial colorants are produced synthetically, including erythrosine (red), cantaxanthin (orange), amaranth (azoic red), tartrazine (azoic yellow), and annatto bixine (yellow orange) [67]. Nonetheless, a few colorants like carotenoids ( $\beta$-carotene, astaxanthin, canthaxanthin, and zeaxanthin) are obtained from natural sources, such as tomato, paprika, and algae [147]. However, synthetic colorants are still used due to their stability and low cost [44]. As agro-food byproducts are usually discarded, their use as a new source of these coloring agents could be a means to shift to more natural colors while still maintaining a low production cost (Table 3).

Table 3. Food byproducts sources of potential colorant food additives. Adapted from Iriondo-DeHond, Miguel, and del Castillo [142].

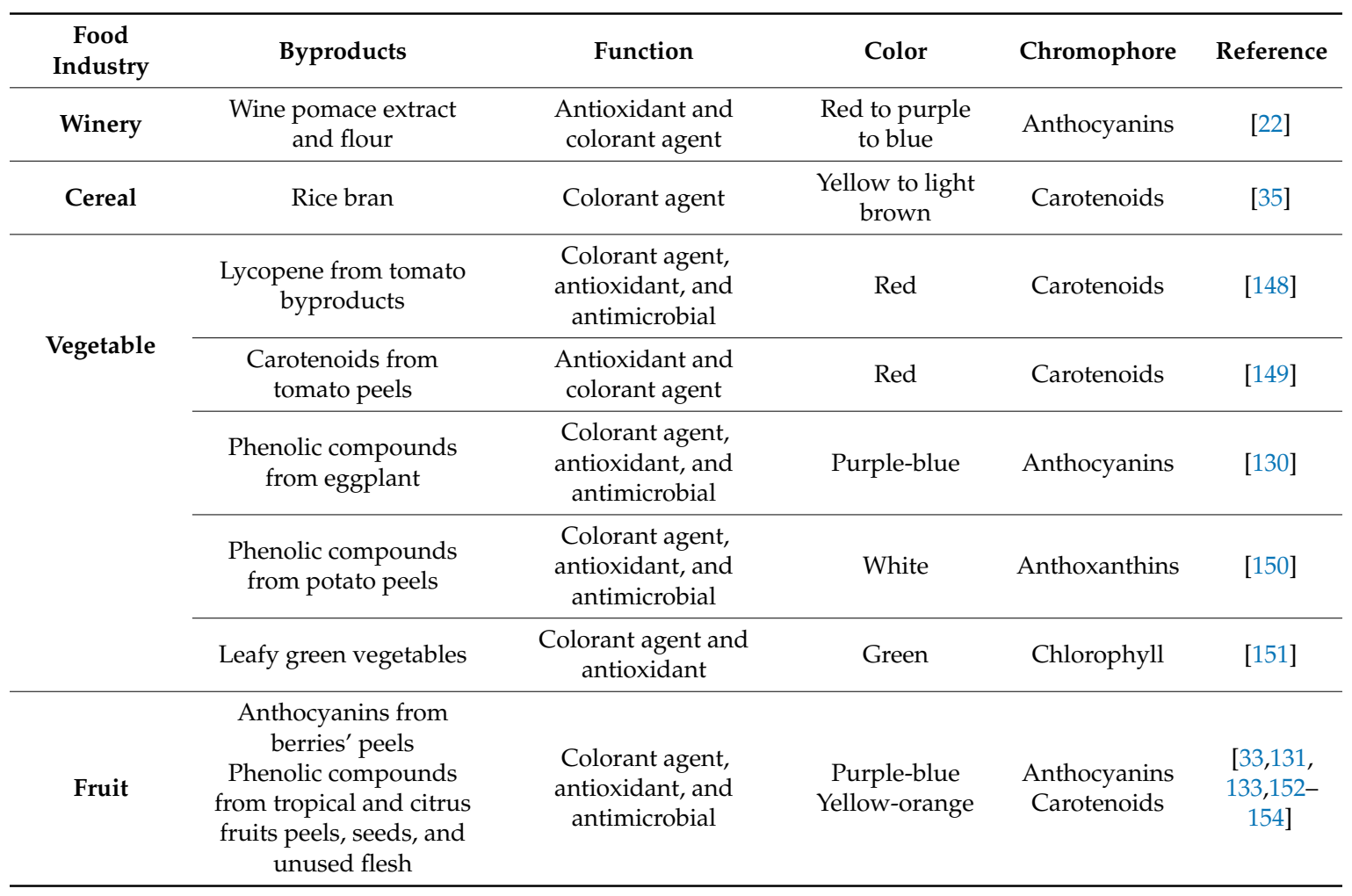

As previously mentioned, consumers have been demanding the replacement of synthetic colorants by natural alternatives. Authors like Siegrist and Sütterlin [155] reported that symbolic information such as the E-numbers on the foodstuff's label influences a consumer's perception of different foodstuff and its origin, with consumers being hesitant to accept the addition of synthetic food additives. Additionally, there have been several reports pertaining to synthetic colorants side effects, including hypersensitive and allergic reactions as well as potential toxicity and carcinogenicity claims [144,156,157]. Natural additives have been associated with health promoting benefits, as they are a part of the bioactive compounds present in fruit and vegetable byproducts. However, the use of these natural pigments can be limited by their lower stability and weaker color strength (when compared to their synthetic counterpart). Additionally, natural additives may confer an undesirable flavor or odor to the food 
products, which will negatively impact the consumer's acceptance $[142,145,158]$. Nonetheless, fruit and vegetable byproducts have become an important potential source of natural pigments, as they are colored by green chlorophylls, yellow-orange-red carotenoids, red-blue-purple anthocyanins, and red betanins [158]. Overall, the main groups of coloring substances found in nature are carotenoids, anthocyanins, porphyrins, and chlorophylls [145,158-160].

Anthocyanins are a good example of natural color additives. These compounds are a group of natural pigments responsible for the blue, red, purple, violet, and magenta coloration of several species in the plant kingdom. They can also be found in extracts of their byproducts. Some examples are winery byproducts, radishes, red potatoes, red cabbage, black carrots, purple sweet potatoes, coffee husks, and berries, among others [106,161].

Carotenoids stand as the major group of compounds used as color additives. These natural pigments are responsible for many of the colors seen in edible fruits, vegetables, mushrooms, flowers, and even lobster and trout hues from the animal kingdom [158]. Much like anthocyanins, carotenoids are produced synthetically ( $\beta$-carotene, astaxanthin, canthaxanthin, and zeaxanthin), although some are obtained from natural sources, namely annatto, marigold, tomato, algae, and microbial fermentation [157]. In addition, these compounds function as sources of provitamin A and are capable of absorbing solar light, oxygen transporters, powerful quenchers of singlet oxygen, as well as other functions not yet studied [160].

The natural pigments were defined in the Regulation (EC) No 1333/2008 of the European Parliament and of the Council of 16 December 2008 and are listed in the Annexes of said regulation [161]. This document includes detailed information on the application of individual pigments in defined food products, their doses, and limitations of use. Presently, 16 natural pigments are permitted: betalains-betanin, quinones-cochineal, flavonoids-anthocyanins, isoprenoids-carotene, annatto (bixin, norbixin), paprika extract, lutein, canthaxanthin, porphyrins-chlorophylls and chlorophyllins, and copper complexes of these compounds, among others, like caramels, curcumin, or plant coal. According to the Regulation (EC) No 1129/2011 [162] of the European Parliament, in the EU, there are 40 color additives legislated for food use.

New technologies such as pulsed-light, high pressure, pulsed-electric, magnetic fields high pressure processing, ionizing radiation, and ultraviolet radiation are being studied and could allow for the use of byproducts as natural source pigments, which could then be exploited as potential new food colorants in the food industry with the advantage of imparting potential health benefits to the consumer as well as contributing to an economical valorization of residues and avoiding waste [163]. For instance, there have been studies regarding the addition of banana peels to biscuits, which resulted in a product with low calories and high dietary fiber content without any significant differences in color, aroma, and taste observed. The banana peel was incorporated at a $10 \%$ and $20 \%$ concentration into the biscuits [164-166]. The peel is the main byproduct of the banana, rich in phytochemical compounds with high antioxidant capacity, such as phenolic compounds, anthocyanins (delphinidin and cyanidin), carotenoids ( $\beta$-carotenoids, $\alpha$-carotenoid, and xanthophylls), catecholamines, sterols, and triterpenes, which, as previously mentioned, could provide different functions as potential food additives besides coloring, namely as antioxidant and antimicrobial components [18,167]. Mango is another example of a fruit with biologically interesting compounds (including phenolic compounds, carotenoids, and dietary fiber) that could be used in the food industry. Most mango byproducts result from the epicarp and endocarp, but it is the mango seed kernel residue with the highest amount of carotenoids in its composition, which is likely due to the amount of fruit pulp left around the kernel by the chopping machine. The carotenoid content was found to be four to eight times higher in ripe mango peels compared to raw fruit peels $[133,165]$. The high levels of bioactive compounds in the mango peel makes this byproduct a potentially valuable raw material for the formulation of additives and supplements for the food industry [168]. Likewise, tomato peel is the main byproduct resulting from the tomato processing industry [169]. The carotenoid pigment lycopene present is the compound responsible for its red color. Tomato lycopene extract and tomato lycopene concentrate from tomato peels have been approved for use as colorants exempt from certification [170]. Oleoresins, 
powders, and water-dispersible preparations that can impart colors from yellow to orange to red are commercially available. An example of the utilization of lycopene from tomato byproducts includes dairy foods, where this compound is applied in the coloring of butter and ice-cream, maintaining a stable reddish color for up to four months [146,148,149].

Even though the use of the aforementioned compounds as food colorants could present an ecological solution to current production issues in addition to possessing an added advantage of potential health benefits, their use has been limited. Regulated colorants from natural sources include anthocyanins (E163), betanin (E162), and carotenoids (E160), including $\beta$-carotene (E160a), lycopene (E160d) (its obtention from tomato processing byproducts has been optimized), lutein (E161b), canthaxanthin (E161g), chlorophyll and chlorophyllin (E140 and E141), and curcumin (E100) [according to Regulation (EC) No 1129/2011] [163]. However, the list of anthocyanin colorants in the Codex Alimentarius includes only grape skin extract (E163), and in the FDA, "grape color extract" and "grape skin extract" (enocyanin) [146,148,149].

Regardless, to include a new pigment as a food colorant additive according to Regulation (EC) No 1333/2008 of the European Parliament and of the Council of 16 December 2008 [162], these new pigments need to be capable of restoring the original appearance of food whose color has been affected by processing, storage, packaging, and distribution, leading to impaired visual acceptability. Thus, colorants need to make food more visually appealing as well as give color to food that is otherwise colorless.

\section{Texturizing Agents}

Texturizing agents, such as emulsifiers, stabilizers, thickeners, and bulking agents, are used in the food industry to modify the overall texture and mouth feel of foodstuffs [171]. Thickeners, when added to the food mixture, increase the viscosity without modifying other food properties, while bulking agents increase the bulk of a food without affecting its nutritional value. Emulsifiers, on the other hand, allow water and oil to remain mixed together in an emulsion. These agents are used to add or modify the texture of food products by modifying the creaminess, thickness, viscosity, or by stabilizing foodstuffs structure [67]. These agents are used in frozen desserts, dairy products, cakes, puddings, gelatin mixes, dressings, jams, jellies, and sauces [172]. An example of the use of these food additives is their incorporation into hydrocolloids like fermented milks, dairy desserts, cream, and ice-cream to stabilize and thicken them. Another example of texture additives are phosphates and coagulation agents that are used in the curdling of milk in cheese production [173]. Most of the hydrocolloids used in the dairy industry result from the isolation of seaweeds and plant cells and are obtained and/or extracted from byproducts such as plant food wastes. The natural agar obtained from algae is the most researched texture agent used as a food additive in bakery products, confectionery, ice cream, peanut butter, and beverages [171]. Table 4 discloses some examples of byproducts used as source of texture additives.

Table 4. Food byproducts sources of potential texturizing agents' additives. Adapted from IriondoDeHond, Miguel and del Castillo [142].

\begin{tabular}{cccc}
\hline Food Industry & Byproducts & Function & Reference \\
\hline & Olive pomace & & {$[142,174,175]$} \\
& Passion fruit peels & & {$[142,174,175]$} \\
& Grape pomace & & {$[142,174,175]$} \\
& Pineapple peel powder & & {$[17]$} \\
Fruit & Pineapple fruit peels & & {$[176]$} \\
& Orange byproducts & Texturizing agent & {$[21,177]$} \\
& Citrus peels & {$[142]$} \\
& Apple pomace & & {$[142]$} \\
& Pear stones & & {$[25]$} \\
& Whey protein & & {$[36,178]$} \\
\multirow{2}{*}{ Dairy } & Whey protein and & & {$[179]$} \\
& Buttermilk & & {$[142]$} \\
& Onion hulls & & {$[25]$} \\
\hline \multirow{2}{*}{ Vegetable } & Spinach &
\end{tabular}


Citrus fruits and their byproducts (such as peels and seed powders) have been studied as possible sources of texturizing agents due to their natural high pectin content and dietary fiber [142,176,180]. Currently, there are some examples of citrus byproducts being used in the industry. Oranges are being used as a texturizing agents in yogurts and/or ice creams [21,179,181], and lemon byproducts are being used as thickening, texturizing, gelling, and stabilizing agents [182]. Furthermore, citrus byproducts have the added advantage of being rich in bioactive compounds, which possess nutritional and functional benefits including reducing the risk of certain pathologies such as obesity, cardiovascular disease, and colon cancer, as well as preventing neurodegenerative diseases and osteoporosis [139,182-185]. Additionally, their high dietary fiber content is an added bonus, as it can be used as fat replacers and thus functions as a food additive to impart texture to the final product [186-188]. In fact, Crizel et al. [189] showed that incorporation of fiber from orange byproducts into yogurts allowed for the manufacture of low-fat yogurts, and Dervisoglu and Yazici [190] reported that while citrus fiber as a single stabilizer did not improve the viscosity, overrun, and sensory properties of ice cream, it improved the melting resistance of these foodstuffs. Similarly, the industrial processing of tomato leads to high amounts of unused matter (mostly peels and seeds), which are byproducts rich in lycopene and dietary fiber. These byproducts have been incorporated in tomato sauce as a food texturizer, with sensorial tasting panels deeming it as acceptable $[149,191]$. Another example is the ß-glucans resulting from cereals such as oat and barley, which have also been used as fat replacers in a variety of foodstuff ranging from baked goods and pasta to beverages and soups with promising results [192-194]. Additionally, the presence of $\beta$-glucans in foods has also been shown to lead to an increase in fiber intake, which in turn prevents constipation, reduces intestinal transit time, reduces the risk of colorectal cancer, and promotes the growth of beneficial intestinal bacteria [195].

Other potential sources of dietary fiber and pectin are cocoa (Theobroma cacao L.) pod husk (an abundant industrial waste with potential application in the food industry), and oat bran. Studies have shown that cocoa byproducts can be used as a texturizing agents after drying and grinding, while juice resulting from the pods can be used to prepare hydrocolloids [196]. On the other hand, oat bran extract has also been studied as a natural emulsifier, with results showing stability through a different range of $\mathrm{pH}$ values, heat treatments, and storage life up to 40 days [197].

On a different note, fat plays an important role in the structural integrity and mouth feeling of foodstuffs (ice-cream and yogurt in particular) due to its interaction with casein micelles [198]. Many different types of fat replacers have been explored in bovine and goat milk yogurts, including the addition of inulin, $\beta$-glucan, high milk protein powder, and whey protein concentrates [199-204]. Whey proteins, obtained as a byproduct of the dairy industry, have many functional properties including gelation, thickening, and water-holding capacity [205]. In the study by Wang et al. [206], whey protein isolate was used to produce a goat's milk yogurt of acceptable quality. Milk fortification with whey protein improved the textural and microstructural characteristics and some sensory characteristics of yogurts. In addition, whey protein concentrates caused some interactions between globular proteins and caseins, which led to an improved texture of goat's milk yogurt and higher water retention capacity [36,206-208]. Whey proteins are also present in high amounts in a byproduct of butter-making-buttermilk. This product is now considered valuable because of its high content in fragments of milk fat globule membrane in addition to phospholipids [209,210]. Studies indicated that the moisture content of cheese supplemented with buttermilk remained high due largely to phospholipids improving its texture [211,212].

\section{Foaming Capacity}

Foam is a colloidal dispersion in which a gaseous phase is dispersed in a liquid or solid phase. Food foams are dependent on the surface activity and film-forming properties of specific protein compounds $[213,214]$. Proteins have to be either very hydrophobic or hydrophilic to possess good foaming properties, and therefore their chemical or enzymatic modification can make them more active on the surface. As such, most foaming agents commonly used in the food industry are mainly 
natural modified food proteins such as soy, casein, egg white, whey, serum proteins isolated from lactoglobulins, and lysozyme [214-216]. Globulins are excellent foaming agents, but their foaming is significantly affected by interactions of the proteins with ovomucine, lysozyme, and, to a lesser extent, ovomucoid, ovotransferrin, and ovalbumin [217]. A novel source of possible foaming agents is the fishery industry, as fish processing leads to high amounts of byproducts rich in collagen and gelatin. This gelatin foaming capacity has been studied, with reports showing that gelatin from shark cartilage possessed foaming properties similar to those of porcine skin [218]. According to Muzaifa et al. [219], fish byproducts (dark muscle, cut offs, viscera, skin, scales, small bones, and fins) could potentially be used to obtain protein hydrolysates through an enzymatic hydrolysis using Alcalase ${ }^{\circledR} 2.4 \mathrm{~L}$ and Flavourzyme ${ }^{\circledR} 500 \mathrm{~L}$, leading to compounds with foaming capacity. Protein hydrolysates obtained from poultry byproducts (head and leg) and rainbow trout (Onchorhynchus mykiss) viscera after an enzymatic hydrolysis using Alcalase ${ }^{\circledR} 2.4 \mathrm{~L}$ also demonstrated foaming capacity [14]. On another work, Kotlar et al. [220] reported on the use of brewer's spent grain (BSG) hydrolysates (attained using a B. cereus extracellular peptidase) to improve the foaming expansion in brewery products. Okara, a byproduct obtained from the soy milk production, was also analyzed for its functional properties, with the authors observing that the isolated proteins from this byproduct could potentially be used as a foaming agent [27]. When it comes to slaughter byproducts, there are several residues, including skin, bones, hooves, muscles, and blood. Blood represents up to $4 \%$ of the animal live weight. However, the direct use of blood in foods is not useful due to the dark color given to the food. In practice, blood is separated by centrifugation into cellular and plasma fractions. Plasma proteins have relevant and interesting properties for food processing [221], e.g., they contribute to cross-link proteins and gelling [222], proteins enrichment [223], as well as emulsifying and foaming agents [224].

\section{Emulsifiers}

Emulsifiers, molecules such as polysaccharides (e.g., gum arabic) or phospholipids (e.g., lecithins) with a surface activity capable of mixing and stabilizing two immiscible phases like water and oil, are largely used in food technology $[225,226]$.

Emulsifier additives can be obtained from a variety of food products (e.g., milk protein isolates) [227] and byproducts (e.g., okara) [27]. Gbogouri, Linder, Fanni, and Parmentier [11] suggested that salmon (Salmo salar) head hydrolysates treated with the commercial enzyme Alcalase ${ }^{\circledR}$ $2.4 \mathrm{~L}$ could potentially be a new source of compounds with great emulsifying capacity and stability. Using the same enzyme mix, Sathivel et al. [13] analyzed the potential of herring (Clupea harengus) byproducts hydrolysates. Although the emulsifying capacity was lower than that of egg albumin and soy protein, the hydrolysates still demonstrated some emulsifying capacity and stability, an effect that was also observed for the protein extracts before hydrolysis [12]. A potential emulsifier additive could be obtained from okara, a byproduct obtained from soymilk production. Even though okara protein isolates had poor solubility, they exhibited other functional properties (emulsification, foaming, and binding properties) that were comparable to those of a commercial soy isolate, further demonstrating the potential use of these isolates as a food ingredient [27]. The Horchata production, a vegetable milk obtained from tiger nuts (Cyperus esculentus), also originates a solid waste byproduct rich in dietary fiber that could potentially be used as a new ingredient for its emulsifying capacity and high emulsifying stability [28]. Emulsifiers can also be found in meat industry byproducts. For example, bovine blood derivate products (plasma and globulin) may be used as a potential new emulsifier agents additive in meat products and others $[28,228,229]$. As such, compounds obtained directly or indirectly from byproducts could potentially be used as new emulsifying agents in the food industry.

\section{Conclusions}

Given the consumer's demand for "clean label" products and the environmental constraints that reinforce the need to change the traditional industrial raw matters with renewable sources, agro-food 
byproducts have appeared as one of the most relevant potential solutions. In fact, some of the additives used nowadays (like anthocyanins and carotenes) can be found in these materials, which makes their extracts interesting from a consumer's perspective (some would prefer a tomato extract instead of traditional lycopene), particularly when considering the possibilities opened up by green, safe, new extraction methodologies like high pressure extraction, ohmic extraction, pulsed electric field, or supercritical extraction. However, their direct inclusion into commercial products may depend on the limitations posed by the legislation itself because, even if the additive itself is already approved for use, should its production process or raw material differ significantly from the one currently used, its future as an additive will be dependent on a new safety evaluation.

Overall, it is possible to see the potential of byproducts derived food additives and potential new additives for application in the food industry. They are an integrated solution with low cost and reduced environmental impact capable of providing alternatives for an industry that relies heavily upon the chemical synthesis compounds. Thus, the use of byproducts as a source of food additives stands out as an economically and environmentally conscious choice and will promote the new era of circular economy.

Author Contributions: M.V., M.F. and P.S. carried out the research and wrote the document, E.M.C. and S.S. were responsible for defining the paper's scope, structure and contributed to its writing and, along with M.P., were responsible for the overall definition and reviewing of the document. All authors reviewed and agreed on the final version.

Funding: This work was supported by National Funds from FCT (grant number UID/Multi/50016/2013, POCI-01-0145-FEDER-016403) from FEDER (grant number PDR2020-101-030775) and from QREN-ANI (grant number 17819).

Conflicts of Interest: The authors declare no conflict of interest.

\section{References}

1. Herrero, M.; Sánchez-Camargo, A.d.P.; Cifuentes, A.; Ibáñez, E. Plants, seaweeds, microalgae and food by-products as natural sources of functional ingredients obtained using pressurized liquid extraction and supercritical fluid extraction. TrAC Trends Anal. Chem. 2015, 71, 26-38. [CrossRef]

2. Fleuri, L.F. Orange and mango by-products: Agro-industrial waste as source of bioactive compounds and botanical versus commercial description-A review AU-Okino Delgado, Clarissa Hamaio. Food Rev. Int. 2016, 32, 1-14. [CrossRef]

3. European Commission. Closing the Loop - An EU Action Plan for the Circular Economy; European Commission: Brussels, Belgium, 2015.

4. Szabo, K.; Cătoi, A.-F.; Vodnar, D.C. Bioactive Compounds Extracted from Tomato Processing by-Products as a Source of Valuable Nutrients. Plant Foods Hum. Nutr. 2018, 73, 268-277. [CrossRef] [PubMed]

5. Abuajah, C.I.; Ogbonna, A.C.; Osuji, C.M. Functional components and medicinal properties of food: A review. J. Food Sci. Technol. 2015, 52, 2522-2529. [CrossRef] [PubMed]

6. Mohamed, S. Functional foods against metabolic syndrome (obesity, diabetes, hypertension and dyslipidemia) and cardiovasular disease. Trends Food Sci. Technol. 2014, 35, 114-128. [CrossRef]

7. Carocho, M.; Morales, P.; Ferreira, I.C. Natural food additives: Quo vadis? Trends Food Sci. Technol. 2015, 45, 284-295. [CrossRef]

8. Liu, R.; Wang, M.; Duan, J.-A. Antipyretic and antioxidant activities of the aqueous extract of Cornu bubali (water buffalo horn). Am. J. Chin. Med. 2010, 38, 293-306. [CrossRef]

9. Banerjee, P.; Shanthi, C. Isolation of novel bioactive regions from bovine Achilles tendon collagen having angiotensin I-converting enzyme-inhibitory properties. Process Biochem. 2012, 47, 2335-2346. [CrossRef]

10. Adje, E.Y.; Balti, R.; Kouach, M.; Dhulster, P.; Guillochon, D.; Nedjar-Arroume, N. Obtaining antimicrobial peptides by controlled peptic hydrolysis of bovine hemoglobin. Int. J. Biol. Macromol. 2011, 49, 143-153. [CrossRef]

11. Gbogouri, G.; Linder, M.; Fanni, J.; Parmentier, M. Influence of hydrolysis degree on the functional properties of salmon byproducts hydrolysates. J. Food Sci. 2004, 69, C615-C622. [CrossRef] 
12. Sathivel, S.; Bechtel, P.J.; Babbitt, J.; Prinyawiwatkul, W.; Negulescu, I.I.; Reppond, K.D. Properties of Protein Powders from Arrowtooth Flounder (Atheresthes stomias) and Herring (Clupea harengus) Byproducts. J. Agric. Food Chem. 2004, 52, 5040-5046. [CrossRef]

13. Sathivel, S.; Bechtel, P.J.; Babbitt, J.; Smiley, S.; Crapo, C.; Reppond, K.D.; Prinyawiwatkul, W. Biochemical and Functional Properties of Herring (Clupea harengus) Byproduct Hydrolysates. J. Food Sci. 2003, 68, 2196-2200. [CrossRef]

14. Taheri, A.; Anvar, S.; Ahari, H.; Fogliano, V. Comparison the functional properties of protein hydrolysates from poultry by-products and rainbow trout (Onchorhynchus mykiss) viscera. Iran. J. Fish. Sci. 2013, 12, 154-169.

15. Ghafoor, K.; Park, J.; Choi, Y.-H. Optimization of supercritical fluid extraction of bioactive compounds from grape (Vitis labrusca B.) peel by using response surface methodology. Innov. Food Sci. Emerg. Technol. 2010, 11, 485-490. [CrossRef]

16. Ersouml, E.; Yerlikaya, O.; Accedil, M. Effect of phenolic compounds on characteristics of strained yoghurts produced from sheep milk. Afr. J. Agric. Res. 2011, 6, 5351-5359.

17. Sah, B.; Vasiljevic, T.; McKechnie, S.; Donkor, O. Physicochemical, textural and rheological properties of probiotic yogurt fortified with fibre-rich pineapple peel powder during refrigerated storage. LWT-Food Sci. Technol. 2016, 65, 978-986. [CrossRef]

18. Someya, S.; Yoshiki, Y.; Okubo, K. Antioxidant compounds from bananas (Musa cavendish). Food Chem. 2002, 79, 351-354. [CrossRef]

19. Shan, B.; Cai, Y.-Z.; Brooks, J.D.; Corke, H. Potential application of spice and herb extracts as natural preservatives in cheese. J. Med. Food 2011, 14, 284-290. [CrossRef]

20. da Silva, D.F.; Matumoto-Pintro, P.T.; Bazinet, L.; Couillard, C.; Britten, M. Effect of commercial grape extracts on the cheese-making properties of milk. J. Dairy Sci. 2015, 98, 1552-1562. [CrossRef]

21. Sendra, E.; Kuri, V.; Fernandez-Lopez, J.; Sayas-Barbera, E.; Navarro, C.; Perez-Alvarez, J. Viscoelastic properties of orange fiber enriched yogurt as a function of fiber dose, size and thermal treatment. LWT-Food Sci. Technol. 2010, 43, 708-714. [CrossRef]

22. Tseng, A.; Zhao, Y. Wine grape pomace as antioxidant dietary fibre for enhancing nutritional value and improving storability of yogurt and salad dressing. Food Chem. 2013, 138, 356-365. [CrossRef] [PubMed]

23. Frumento, D.; do Espirito Santo, A.P.; Aliakbarian, B.; Casazza, A.A.; Gallo, M.; Converti, A.; Perego, P. Development of milk fermented with Lactobacillus acidophilus fortified with Vitis vinifera marc flour. Food Technol. Biotechnol. 2013, 51, 370.

24. Pazmiño, A.; Giusti, M.; Wrolstad, R.; Gloria, M.B.A. Anthocyanins from banana bracts (Musa X Paradisiaca) as potential food colorants. Food Chem. 2001, 73, 327-332.

25. Saraç, M.G.; Dogan, M. Incorporation of dietary fiber concentrates from fruit and vegetable wastes in butter: Effects on physicochemical, textural, and sensory properties. Eur. Food Res. Technol. 2016, 242, 1331-1342. [CrossRef]

26. Padam, B.; Tin, H.; Chye, F.; Abdullah, M. Antibacterial and Antioxidative Activities of the Various Solvent Extracts of Banana (Musa paradisiaca cv. Mysore) Inflorescences. J. Biol. Sci. 2012, 12, 62-73.

27. Ma, C.-Y.; Liu, W.-S.; Kwok, K.C.; Kwok, F. Isolation and characterization of proteins from soymilk residue (okara). Food Res. Int. 1996, 29, 799-805. [CrossRef]

28. Sanchez-Zapata, E.; Fuentes-Zaragoza, E.L.; Fernandez-Lopez, J.; Sendra, E.; Sayas, E.; Navarro, C.; Pérez-Álvarez, J.A. Preparation of dietary fiber powder from tiger nut (Cyperus esculentus) milk ("Horchata") byproducts and its physicochemical properties. J. Agric. Food Chem. 2009, 57, 7719-7725. [CrossRef]

29. Ciurlia, L.; Bleve, M.; Rescio, L. Supercritical carbon dioxide co-extraction of tomatoes (Lycopersicum esculentum L.) and hazelnuts (Corylus avellana L.): A new procedure in obtaining a source of natural lycopene. J. Supercrit. Fluids 2009, 49, 338-344. [CrossRef]

30. Viuda-Martos, M.; Sanchez-Zapata, E.; Sayas-Barberá, E.; Sendra, E.; Pérez-Álvarez, J.; Fernández-López, J. Tomato and tomato byproducts. Human health benefits of lycopene and its application to meat products: A review. Crit. Rev. Food Sci. Nutr. 2014, 54, 1032-1049. [CrossRef]

31. Jurikova, T.; Skrovankova, S.; Mlcek, J.; Balla, S.; Snopek, L. Bioactive Compounds, Antioxidant Activity, and Biological Effects of European Cranberry (Vaccinium oxycoccos). Molecules 2018, 24, 24. [CrossRef]

32. Al-Zoreky, N. Antimicrobial activity of pomegranate (Punica granatum L.) fruit peels. Int. J. Food Microbiol. 2009, 134, 244-248. [CrossRef] 
33. Akhtar, S.; Ismail, T.; Fraternale, D.; Sestili, P. Pomegranate peel and peel extracts: Chemistry and food features. Food Chem. 2015, 174, 417-425. [CrossRef]

34. Abid, Y.; Azabou, S.; Jridi, M.; Khemakhem, I.; Bouaziz, M.; Attia, H. Storage stability of traditional Tunisian butter enriched with antioxidant extract from tomato processing by-products. Food Chem. 2017, 233, 476-482. [CrossRef]

35. Nontasan, S.; Moongngarm, A.; Deeseenthum, S. Application of Functional Colorant Prepared from Black Rice Bran in Yogurt. APCBEE Procedia 2012, 2, 62-67. [CrossRef]

36. Akalın, A.; Unal, G.; Dinkci, N.; Hayaloglu, A. Microstructural, textural, and sensory characteristics of probiotic yogurts fortified with sodium calcium caseinate or whey protein concentrate. J. Dairy Sci. 2012, 95, 3617-3628. [CrossRef]

37. Peters, H. M. Hanssen und J. Marschen: E for Additives. 223 Seiten. Thorsons Publishers Limited, Wellingborough, Northamptonshire. 1984. Preis: 2.95 £. Food Nahr. 1986, 30, 204. [CrossRef]

38. Saltmarsh, M. Recent trends in the use of food additives in the United Kingdom. J. Sci. Food Agric. 2015, 95, 649-652. [CrossRef]

39. Aschemann-Witzel, J.; Varela, P.; Peschel, A.O. Consumers' categorization of food ingredients: Do consumers perceive them as 'clean label' producers expect? An exploration with projective mapping. Food Qual. Prefer. 2019, 71, 117-128. [CrossRef]

40. Asioli, D.; Aschemann-Witzel, J.; Caputo, V.; Vecchio, R.; Annunziata, A.; Næs, T.; Varela, P. Making sense of the "clean label" trends: A review of consumer food choice behavior and discussion of industry implications. Food Res. Int. 2017, 99, 58-71. [CrossRef]

41. Ayala-Zavala, J.; Vega-Vega, V.; Rosas-Domínguez, C.; Palafox-Carlos, H.; Villa-Rodriguez, J.; Siddiqui, M.W.; Dávila-Aviña, J.; González-Aguilar, G. Agro-industrial potential of exotic fruit byproducts as a source of food additives. Food Res. Int. 2011, 44, 1866-1874. [CrossRef]

42. Ofori, J.A.; Hsieh, Y.-H.P. The use of blood and derived products as food additives. In Food Additive; IntechOpen: Rijeka, Croatia, 2012.

43. Schieber, A.; Stintzing, F.; Carle, R. By-products of plant food processing as a source of functional compounds-Recent developments. Trends Food Sci. Technol. 2001, 12, 401-413. [CrossRef]

44. Gowe, C. Review on potential use of fruit and vegetables by-products as a valuable source of natural food additives. Food Sci. Qual. Manag. 2015, 45, 47-61.

45. EU. Regulation (EC) No 1333/2008 of the European Parliament and of the Council of 16 December 2008 on food additives (1). Off. J. Eur. Union 2009, 51, 16-33.

46. EU. Commission Directive 2008/60/EC of 17 June 2008 laying down specific purity criteria concerning sweeteners for use in foodstuffs (Codified version). Off. J. Eur. Union 2008, 158, 17-40.

47. EU. Commission Directive 2008/128/EC of 22 December 2008 laying down specific purity criteria concerning colours for use in foodstuffs (Codified version). Off. J. Eur. Union 2009, 52, 20-63.

48. EU. Commission Directive 2008/84/EC of 27 August 2008 laying down specific purity criteria on food additives other than colours and sweeteners (Codified version). Off. J. Eur. Union 2009, 51, 1-175.

49. Saltmarsh, M. Essential Guide to Food Additives; Royal Society of Chemistry: London, UK, 2013.

50. EU. Commission Regulation (EU) No 231/2012 of 9 March 2012 laying down specifications for food additives listed in Annexes II and III to Regulation (EC) No 1333/2008. Off. J. Eur. Union 2012, 55, 1-295. [CrossRef]

51. Rajha, H.N.; El Darra, N.; Hobaika, Z.; Boussetta, N.; Vorobiev, E.; Maroun, R.G.; Louka, N. Extraction of total phenolic compounds, flavonoids, anthocyanins and tannins from grape byproducts by response surface methodology. Influence of solid-liquid ratio, particle size, time, temperature and solvent mixtures on the optimization process. Food Nutr. Sci. 2014, 5, 397. [CrossRef]

52. Corrales, M.; Toepfl, S.; Butz, P.; Knorr, D.; Tauscher, B. Extraction of anthocyanins from grape by-products assisted by ultrasonics, high hydrostatic pressure or pulsed electric fields: A comparison. Innov. Food Sci. Emerg. Technol. 2008, 9, 85-91. [CrossRef]

53. Kalogeropoulos, N.; Chiou, A.; Pyriochou, V.; Peristeraki, A.; Karathanos, V.T. Bioactive phytochemicals in industrial tomatoes and their processing byproducts. LWT-Food Sci. Technol. 2012, 49, 213-216. [CrossRef]

54. Ajila, C.; Naidu, K.; Bhat, S.; Rao, U.P. Bioactive compounds and antioxidant potential of mango peel extract. Food Chem. 2007, 105, 982-988. [CrossRef]

55. Dabbou, S.; Dabbou, S.; Flamini, G.; Pandino, G.; Gasco, L.; Helal, A.N. Phytochemical compounds from the crop byproducts of Tunisian globe artichoke cultivars. Chem. Biodivers. 2016, 13, 1475-1483. [CrossRef] 
56. Gapor, A.; Kato, A.; Ong, A. Tocopherol content in oil palm leaflet. J. Am. Oil Chem. Soc. 1986, 63, 330-331. [CrossRef]

57. Baysal, T.; Ersus, S.; Starmans, D. Supercritical $\mathrm{CO}_{2}$ extraction of $\beta$-carotene and lycopene from tomato paste waste. J. Agric. Food Chem. 2000, 48, 5507-5511. [CrossRef]

58. Gherezgihier, B.A.; Mahmud, A.; Admassu, H.; Shui, X.W.; Fang, Y.; Tsighe, N.; Mohammed, J.K. Food additives: Functions, effects, regulations, approval and safety evaluation. J. Acad. Ind. Res. 2017, 6, 62-68.

59. Millstone, E. A. Larry Branen, P. Michael Davidson, Seppe Salminen and John H. ThorngateIII (editors). Food Additives, 2nd ed. New York and Basel: Marcel Dekker Inc.. 2001. US\$225. pp. XV + 938, ISBN 0824793439. Br. J. Nutr. 2007, 89, 157-158. [CrossRef]

60. Food and Drug Administration Center for Food Safety and Applied Nutrition. Guidance for Industry Considerations Regarding Substances Added to Foods, Including Beverages and Dietary Supplements; Food and Drug Administration Center for Food Safety and Applied Nutrition, U.S. Department of Health and Human Services: College Park, MD, USA, 2014.

61. EFSA Panel on Food Additives and Nutrient Sources added to Food (ANS). Guidance for submission for food additive evaluations. EFSA J. 2012, 10, 2760. [CrossRef]

62. Gram, L.; Ravn, L.; Rasch, M.; Bruhn, J.B.; Christensen, A.B.; Givskov, M. Food spoilage-Interactions between food spoilage bacteria. Int. J. Food Microbiol. 2002, 78, 79-97. [CrossRef]

63. Perumalla, A.; Hettiarachchy, N.S. Green tea and grape seed extracts-Potential applications in food safety and quality. Food Res. Int. 2011, 44, 827-839. [CrossRef]

64. McCabe-Sellers, B.J.; Beattie, S.E. Food safety: Emerging trends in foodborne illness surveillance and prevention. J. Am. Diet. Assoc. 2004, 104, 1708-1717. [CrossRef]

65. Pitt, J.I.; Hocking, A.D. The ecology of fungal food spoilage. In Fungi and Food Spoilage; Springer: New York, NY, USA, 2009; pp. 3-9.

66. Lück, E.; Jager, M. Antimicrobial Food Additives: Characteristics, Uses, Effects; Springer Science \& Business Media: New York, NY, USA, 1997; Volume 2.

67. Abdulmumeen, H.A.; Risikat, A.N.; Sururah, A.R. Food: Its preservatives, additives and applications. Int. J. Pharm. Chem. Biol. Sci. 2012, 1, 36-47.

68. Smith, J.; Hong-Shum, L. Food Additives Data Book; John Wiley \& Sons: New York, NY, USA, 2011.

69. O'sullivan, L.; Ross, R.; Hill, C. Potential of bacteriocin-producing lactic acid bacteria for improvements in food safety and quality. Biochimie 2002, 84, 593-604. [CrossRef]

70. Burt, S. Essential oils: Their antibacterial properties and potential applications in foods-A review. Int. J. Food Microbiol. 2004, 94, 223-253. [CrossRef]

71. Ohtsu, N.; Kohari, Y.; Gotoh, M.; Yamada, R.; Nagata, Y.; Murata, M. Utilization of the Japanese Peppermint Herbal Water Byproduct of Steam Distillation as an Antimicrobial Agent. J. Oleo Sci. 2018, 67, 1227-1233. [CrossRef]

72. Sanz-Puig, M.; Pina-Pérez, M.C.; Criado, M.N.; Rodrigo, D.; Martínez-López, A. Antimicrobial potential of cauliflower, broccoli, and okara byproducts against foodborne bacteria. Foodborne Pathog. Dis. 2015, 12, 39-46. [CrossRef]

73. Li, C.; Li, X.; Bai, C.; Zhang, Y.; Wang, Z. A chitinase with antifungal activity from naked oat (Avena chinensis) seeds. J. Food Biochem. 2018, e12713. [CrossRef]

74. Kirbaşlar, F.G.; Tavman, A.; Dülger, B.; Türker, G. Antimicrobial activity of Turkish citrus peel oils. Pak. J. Bot. 2009, 41, 3207-3212.

75. Smith-Palmer, A.; Stewart, J.; Fyfe, L. Antimicrobial properties of plant essential oils and essences against five important food-borne pathogens. Lett. Appl. Microbiol. 1998, 26, 118-122. [CrossRef]

76. Fisher, K.; Phillips, C. Potential antimicrobial uses of essential oils in food: Is citrus the answer? Trends Food Sci. Technol. 2008, 19, 156-164. [CrossRef]

77. Ayala-Zavala, J.F.; González-Aguilar, G.A. Use of additives to preserve the quality of fresh-cut fruits and vegetables. In Advances in Fresh-Cut Fruits and Vegetables Processing; CRC Press: Boca Raton, FL, USA, 2010; pp. 233-256.

78. Correa, P. Diet and gastric cancer. In Diet, Nutrition and Cancer: A Critical Evaluation; CRC Press: Boca Raton, FL, USA, 2018; pp. 1-10.

79. Gassara, F.; Kouassi, A.P.; Brar, S.K.; Belkacemi, K. Green alternatives to nitrates and nitrites in meat-based products-A review. Crit. Rev. Food Sci. Nutr. 2016, 56, 2133-2148. [CrossRef] 
80. Keeton, J.T. History of nitrite and nitrate in food. In Nitrite and Nitrate in Human Health and Disease; Springer: New York, NY, USA, 2017; pp. 85-97.

81. Adam, A.H.B.; Mustafa, N.E.M.; Rietjens, I.M. Nitrite in processed meat products in Khartoum, Sudan and dietary intake. Food Addit. Contam. Part B 2017, 10, 79-84. [CrossRef] [PubMed]

82. Jiang, J.; Xiong, Y.L. Natural antioxidants as food and feed additives to promote health benefits and quality of meat products: A review. Meat Sci. 2016, 120, 107-117. [CrossRef]

83. Gul, P.; Bakht, J. Antimicrobial activity of turmeric extract and its potential use in food industry. J. Food Sci. Technol. 2015, 52, 2272-2279. [CrossRef]

84. Veiga, R.; De Mendonça, S.; Mendes, P.; Paulino, N.; Mimica, M.; Lagareiro Netto, A.; Lira, I.; López, B.C.; Negrão, V.; Marcucci, M. Artepillin C and phenolic compounds responsible for antimicrobial and antioxidant activity of green propolis and Baccharis dracunculifolia DC. J. Appl. Microbiol. 2017, 122, 911-920. [CrossRef] [PubMed]

85. Cueva, C.; Moreno-Arribas, M.V.; Martín-Álvarez, P.J.; Bills, G.; Vicente, M.F.; Basilio, A.; Rivas, C.L.; Requena, T.; Rodríguez, J.M.; Bartolomé, B. Antimicrobial activity of phenolic acids against commensal, probiotic and pathogenic bacteria. Res. Microbiol. 2010, 161, 372-382. [CrossRef] [PubMed]

86. Maizura, M.; Aminah, A.; Wan Aida, W. Total phenolic content and antioxidant activity of kesum (Polygonum minus), ginger (Zingiber officinale) and turmeric (Curcuma longa) extract. Int. Food Res. J. 2011, 18.

87. Negi, P.; Jayaprakasha, G.; Jagan Mohan Rao, L.; Sakariah, K. Antibacterial activity of turmeric oil: A byproduct from curcumin manufacture. J. Agric. Food Chem. 1999, 47, 4297-4300. [CrossRef] [PubMed]

88. Hu, Y.; Zhang, J.; Kong, W.; Zhao, G.; Yang, M. Mechanisms of antifungal and anti-aflatoxigenic properties of essential oil derived from turmeric (Curcuma longa L.) on Aspergillus flavus. Food Chem. 2017, 220, 1-8. [CrossRef]

89. Nile, S.H.; Park, S.W. Edible berries: Bioactive components and their effect on human health. Nutrition 2014, 30, 134-144. [CrossRef]

90. Paredes-López, O.; Cervantes-Ceja, M.L.; Vigna-Pérez, M.; Hernández-Pérez, T. Berries: Improving human health and healthy aging, and promoting quality life-A review. Plant Foods Hum. Nutr. 2010, 65, $299-308$. [CrossRef]

91. Nicoue, E.E.; Savard, S.; Belkacemi, K. Anthocyanins in wild blueberries of Quebec: Extraction and identification. J. Agric. Food Chem. 2007, 55, 5626-5635. [CrossRef] [PubMed]

92. Veiga, M.; Costa, E.M.; Silva, S.; Pintado, M. Impact of plant extracts upon human health: A review. Crit. Rev. Food Sci. Nutr. 2018, 1-14. [CrossRef] [PubMed]

93. Silva, S.; Costa, E.M.; Mendes, M.; Morais, R.; Calhau, C.; Pintado, M. Antimicrobial, antiadhesive and antibiofilm activity of an ethanolic, anthocyanin-rich blueberry extract purified by solid phase extraction. J. Appl. Microbiol. 2016, 121, 693-703. [CrossRef] [PubMed]

94. Silva, S.; Costa, E.M.; Costa, M.R.; Pereira, M.F.; Pereira, J.O.; Soares, J.C.; Pintado, M.M. Aqueous extracts of Vaccinium corymbosum as inhibitors of Staphylococcus aureus. Food Control 2015, 51, 314-320. [CrossRef]

95. Puupponen-Pimiä, R.; Nohynek, L.; Meier, C.; Kähkönen, M.; Heinonen, M.; Hopia, A.; Oksman-Caldentey, K.M. Antimicrobial properties of phenolic compounds from berries. J. Appl. Microbiol. 2001, 90, 494-507. [CrossRef] [PubMed]

96. Ross, K.; Ehret, D.; Godfrey, D.; Fukumoto, L.; Diarra, M. Characterization of Pilot Scale Processed Canadian Organic Cranberry (Vaccinium macrocarpon) and Blueberry (Vaccinium angustifolium) Juice Pressing Residues and Phenolic-Enriched Extractives. Int. J. Fruit Sci. 2017, 17, 202-232. [CrossRef]

97. Neto, C.C. Cranberry and blueberry: Evidence for protective effects against cancer and vascular diseases. Mol. Nutr. Food Res. 2007, 51, 652-664. [CrossRef] [PubMed]

98. Talhaoui, N.; Taamalli, A.; Gómez-Caravaca, A.M.; Fernández-Gutiérrez, A.; Segura-Carretero, A. Phenolic compounds in olive leaves: Analytical determination, biotic and abiotic influence, and health benefits. Food Res. Int. 2015, 77, 92-108. [CrossRef]

99. Şahin, S.; Samli, R.; Tan, A.S.B.; Barba, F.J.; Chemat, F.; Cravotto, G.; Lorenzo, J.M. Solvent-free microwave-assisted extraction of polyphenols from olive tree leaves: Antioxidant and antimicrobial properties. Molecules 2017, 22, 1056. [CrossRef]

100. Paiva-Martins, F.; Correia, R.; Félix, S.; Ferreira, P.; Gordon, M.H. Effects of enrichment of refined olive oil with phenolic compounds from olive leaves. J. Agric. Food Chem. 2007, 55, 4139-4143. [CrossRef] 
101. Pereira, A.P.; Ferreira, I.C.; Marcelino, F.; Valentão, P.; Andrade, P.B.; Seabra, R.; Estevinho, L.; Bento, A.; Pereira, J.A. Phenolic compounds and antimicrobial activity of olive (Olea europaea L. Cv. Cobrançosa) leaves. Molecules 2007, 12, 1153-1162. [CrossRef] [PubMed]

102. Wang, Y.; Li, F.; Zhuang, H.; Chen, X.; Li, L.; Qiao, W.; Zhang, J. Effects of plant polyphenols and $\alpha$-tocopherol on lipid oxidation, residual nitrites, biogenic amines, and $\mathrm{N}$-nitrosamines formation during ripening and storage of dry-cured bacon. LWT-Food Sci. Technol. 2015, 60, 199-206. [CrossRef]

103. Kondo, M.; Kita, K.; Yokota, H.-O. Feeding value to goats of whole-crop oat ensiled with green tea waste. Anim. Feed Sci. Technol. 2004, 113, 71-81. [CrossRef]

104. Farhoosh, R.; Golmovahhed, G.A.; Khodaparast, M.H. Antioxidant activity of various extracts of old tea leaves and black tea wastes (Camellia sinensis L.). Food Chem. 2007, 100, 231-236. [CrossRef]

105. García-Lomillo, J.; Gonzalez-SanJose, M.L.; Del Pino-García, R.; Rivero-Perez, M.D.; Muniz-Rodriguez, P. Antioxidant and antimicrobial properties of wine byproducts and their potential uses in the food industry. J. Agric. Food Chem. 2014, 62, 12595-12602. [CrossRef]

106. Teixeira, A.; Baenas, N.; Dominguez-Perles, R.; Barros, A.; Rosa, E.; Moreno, A.D.; Garcia-Viguera, C. Natural Bioactive Compounds from Winery By-Products as Health Promoters: A Review. Int. J. Mol. Sci. 2014, 15, 15638-15678. [CrossRef]

107. Çam, M.; İçyer, N.C.; Erdoğan, F. Pomegranate peel phenolics: Microencapsulation, storage stability and potential ingredient for functional food development. LWT-Food Sci. Technol. 2014, 55, 117-123. [CrossRef]

108. Li, Y.; Guo, C.; Yang, J.; Wei, J.; Xu, J.; Cheng, S. Evaluation of antioxidant properties of pomegranate peel extract in comparison with pomegranate pulp extract. Food Chem. 2006, 96, 254-260. [CrossRef]

109. Kanatt, S.R.; Chander, R.; Sharma, A. Antioxidant and antimicrobial activity of pomegranate peel extract improves the shelf life of chicken products. Int. J. Food Sci. Technol. 2010, 45, 216-222. [CrossRef]

110. Rodríguez-Carpena, J.-G.; Morcuende, D.; Andrade, M.-J.; Kylli, P.; Estévez, M. Avocado (Persea americana Mill.) phenolics, in vitro antioxidant and antimicrobial activities, and inhibition of lipid and protein oxidation in porcine patties. J. Agric. Food Chem. 2011, 59, 5625-5635. [CrossRef]

111. Raymond Chia, T.W.; Dykes, G.A. Antimicrobial activity of crude epicarp and seed extracts from mature avocado fruit (Persea americana) of three cultivars. Pharm. Biol. 2010, 48, 753-756. [CrossRef]

112. Calderón-Oliver, M.; Escalona-Buendía, H.B.; Medina-Campos, O.N.; Pedraza-Chaverri, J.; Pedroza-Islas, R.; Ponce-Alquicira, E. Optimization of the antioxidant and antimicrobial response of the combined effect of nisin and avocado byproducts. LWT-Food Sci. Technol. 2016, 65, 46-52. [CrossRef]

113. Baines, D.; Seal, R. Natural Food Additives, Ingredients and Flavourings; Elsevier: Amsterdam, The Netherlands, 2012.

114. Sung, K.; Khan, S.A.; Nawaz, M.S.; Cerniglia, C.E.; Tamplin, M.L.; Phillips, R.W.; Kelley, L.C. Lysozyme as a barrier to growth of Bacillus anthracis strain Sterne in liquid egg white, milk and beef. Food Microbiol. 2011, 28, 1231-1234. [CrossRef]

115. Barbiroli, A.; Bonomi, F.; Capretti, G.; Iametti, S.; Manzoni, M.; Piergiovanni, L.; Rollini, M. Antimicrobial activity of lysozyme and lactoferrin incorporated in cellulose-based food packaging. Food Control 2012, 26, 387-392. [CrossRef]

116. Lorenzo, J.M.; Munekata, P.E.; Gómez, B.; Barba, F.J.; Mora, L.; Pérez-Santaescolástica, C.; Toldrá, F. Bioactive peptides as natural antioxidants in food products-A review. Trends Food Sci. Technol. 2018, 79, 136-147. [CrossRef]

117. Carocho, M.; Morales, P.; Ferreira, I.C. Antioxidants: Reviewing the chemistry, food applications, legislation and role as preservatives. Trends Food Sci. Technol. 2018, 71, 107-120. [CrossRef]

118. Roca-Saavedra, P.; Mendez-Vilabrille, V.; Miranda, J.M.; Nebot, C.; Cardelle-Cobas, A.; Franco, C.M.; Cepeda, A. Food additives, contaminants and other minor components: Effects on human gut microbiota-A review. J. Physiol. Biochem. 2017, 1-15. [CrossRef]

119. Pisoschi, A.M.; Pop, A. The role of antioxidants in the chemistry of oxidative stress: A review. Eur. J. Med. Chem. 2015, 97, 55-74. [CrossRef]

120. Di Pasquale, J.; Adinolfi, F.; Capitanio, F. Analysis of consumer attitudes and consumers' willingness to pay for functional foods. Int. J. Food Syst. Dyn. 2011, 2, 181-193.

121. Caleja, C.; Barros, L.; Antonio, A.L.; Oliveira, M.B.P.; Ferreira, I.C. A comparative study between natural and synthetic antioxidants: Evaluation of their performance after incorporation into biscuits. Food Chem. 2017, 216, 342-346. [CrossRef] 
122. Williams, G.; Iatropoulos, M.; Whysner, J. Safety assessment of butylated hydroxyanisole and butylated hydroxytoluene as antioxidant food additives. Food Chem. Toxicol. 1999, 37, 1027-1038. [CrossRef]

123. Wu, D.; Yan, J.; Tang, P.; Li, S.; Xu, K.; Li, H. Binding properties and structure-affinity relationships of food antioxidant butylated hydroxyanisole and its metabolites with lysozyme. Food Chem. 2015, 188, 370-376. [CrossRef]

124. Taghvaei, M.; Jafari, S.M. Application and stability of natural antioxidants in edible oils in order to substitute synthetic additives. J. Food Sci. Technol. 2015, 52, 1272-1282. [CrossRef]

125. McCusker, M.M.; Durrani, K.; Payette, M.J.; Suchecki, J. An eye on nutrition: The role of vitamins, essential fatty acids, and antioxidants in age-related macular degeneration, dry eye syndrome, and cataract. Clin. Dermatol. 2016, 34, 276-285. [CrossRef]

126. Toldrá, F.; Mora, L.; Reig, M. New insights into meat by-product utilization. Meat Sci. 2016, 120, 54-59. [CrossRef]

127. Ryder, K.; Ha, M.; Bekhit, A.E.-D.; Carne, A. Characterisation of novel fungal and bacterial protease preparations and evaluation of their ability to hydrolyse meat myofibrillar and connective tissue proteins. Food Chem. 2015, 172, 197-206. [CrossRef]

128. Roldán, E.; Sánchez-Moreno, C.; de Ancos, B.; Cano, M.P. Characterisation of onion (Allium cepa L.) by-products as food ingredients with antioxidant and antibrowning properties. Food Chem. 2008, 108, 907-916. [CrossRef]

129. Larrosa, M.; Llorach, R.; Espín, J.C.; Tomás-Barberán, F.A. Increase of antioxidant activity of tomato juice upon functionalisation with vegetable byproduct extracts. LWT-Food Sci. Technol. 2002, 35, 532-542. [CrossRef]

130. Sadilova, E.; Stintzing, F.C.; Carle, R. Anthocyanins, colour and antioxidant properties of eggplant (Solanum melongena L.) and violet pepper (Capsicum annuum L.) peel extracts. Z. Nat. C 2006, 61, 527-535. [CrossRef]

131. Kim, H.; Moon, J.Y.; Kim, H.; Lee, D.-S.; Cho, M.; Choi, H.-K.; Kim, Y.S.; Mosaddik, A.; Cho, S.K. Antioxidant and antiproliferative activities of mango (Mangifera indica L.) flesh and peel. Food Chem. 2010, 121, 429-436. [CrossRef]

132. Vega-Vega, V.; Silva-Espinoza, B.A.; Cruz-Valenzuela, M.R.; Bernal-Mercado, A.T.; Gonzalez-Aguilar, G.A.; Ruiz-Cruz, S.; Moctezuma, E.; Siddiqui, M.W.; Ayala-Zavala, J.F. Antimicrobial and antioxidant properties of byproduct extracts of mango fruit. J. Appl. Bot. Food Qual. 2013, 86. [CrossRef]

133. Ajila, C.M.; Aalami, M.; Leelavathi, K.; Rao, U.J.S.P. Mango peel powder: A potential source of antioxidant and dietary fiber in macaroni preparations. Innov. Food Sci. Emerg. Technol. 2010, 11, 219-224. [CrossRef]

134. Caleja, C.; Barros, L.; Antonio, A.L.; Ciric, A.; Barreira, J.C.; Sokovic, M.; Oliveira, M.B.P.; Santos-Buelga, C.; Ferreira, I.C. Development of a functional dairy food: Exploring bioactive and preservation effects of chamomile (Matricaria recutita L.). J. Funct. Foods 2015, 16, 114-124. [CrossRef]

135. Caleja, C.; Barros, L.; Antonio, A.L.; Ciric, A.; Soković, M.; Oliveira, M.B.P.; Santos-Buelga, C.; Ferreira, I.C. Foeniculum vulgare Mill. as natural conservation enhancer and health promoter by incorporation in cottage cheese. J. Funct. Foods 2015, 12, 428-438. [CrossRef]

136. Shah, M.A.; Bosco, S.J.D.; Mir, S.A. Plant extracts as natural antioxidants in meat and meat products. Meat Sci. 2014, 98, 21-33. [CrossRef]

137. Bajaj, S.; Urooj, A.; Prabhasankar, P. Effect of incorporation of mint on texture, colour and sensory parameters of biscuits. Int. J. Food Prop. 2006, 9, 691-700. [CrossRef]

138. He, B.; Zhang, L.-L.; Yue, X.-Y.; Liang, J.; Jiang, J.; Gao, X.-L.; Yue, P.-X. Optimization of ultrasound-assisted extraction of phenolic compounds and anthocyanins from blueberry (Vaccinium ashei) wine pomace. Food Chem. 2016, 204, 70-76. [CrossRef]

139. Guimarães, R.; Barros, L.; Barreira, J.C.; Sousa, M.J.; Carvalho, A.M.; Ferreira, I.C. Targeting excessive free radicals with peels and juices of citrus fruits: Grapefruit, lemon, lime and orange. Food Chem. Toxicol. 2010, 48, 99-106. [CrossRef]

140. Prakash, C.V.S.; Prakash, I. Bioactive chemical constituents from pomegranate (Punica granatum) juice, seed and peel-A review. IJRCE 2011, 1, 1-18.

141. Verbeke, W. Functional foods: Consumer willingness to compromise on taste for health? Food Qual. Prefer. 2006, 17, 126-131. [CrossRef]

142. Iriondo-DeHond, M.; Miguel, E.; del Castillo, M. Food Byproducts as Sustainable Ingredients for Innovative and Healthy Dairy Foods. Nutrients 2018, 10, 1358. [CrossRef] 
143. Codex Alimentarius General Standard for Food Additives; Food and Agriculture Organization of the United Nations: Rome, Italy, 1995; Volume 192.

144. Amchova, P.; Kotolova, H.; Ruda-Kucerova, J. Health safety issues of synthetic food colorants. Regul. Toxicol. Pharmacol. 2015, 73, 914-922. [CrossRef] [PubMed]

145. Sigurdson, G.T.; Tang, P.; Giusti, M.M. Natural colorants: Food colorants from natural sources. Annu. Rev. Food Sci. Technol. 2017, 8, 261-280. [CrossRef] [PubMed]

146. Bridle, P.; Timberlake, C.F. Anthocyanins as natural food colours-Selected aspects. Food Chem. 1997, 58, 103-109. [CrossRef]

147. Rodriguez-Amaya, D.B. Natural food pigments and colorants. Curr. Opin. Food Sci 2016, 7, 20-26. [CrossRef]

148. Kaur, D.; Wani, A.A.; Singh, D.P.; Sogi, D.S. Shelf Life Enhancement of Butter, Ice-Cream, and Mayonnaise by Addition of Lycopene. Int. J. Food Prop. 2011, 14, 1217-1231. [CrossRef]

149. Rizk, E.M.; El-Kady, A.T.; El-Bialy, A.R. Characterization of carotenoids (lyco-red) extracted from tomato peels and its uses as natural colorants and antioxidants of ice cream. Ann. Agric. Sci. 2014, 59, 53-61. [CrossRef]

150. De Ancos, B.; Colina-Coca, C.; González-Peña, D.; Sánchez-Moreno, C. Bioactive compounds from vegetable and fruit by-products. Biotechnol. Bioact. Compd. Sources Appl. 2015, 1-36. [CrossRef]

151. Chaitanya Lakshmi, G. Food coloring: The natural way. Res. J. Chem. Sci. 2014, 2231, 606X.

152. Ajila, C.; Leelavathi, K.; Rao, U.P. Improvement of dietary fiber content and antioxidant properties in soft dough biscuits with the incorporation of mango peel powder. J. Cereal Sci. 2008, 48, 319-326. [CrossRef]

153. Tung, Y.-C.; Chang, W.-T.; Li, S.; Wu, J.-C.; Badmeav, V.; Ho, C.-T.; Pan, M.-H. Citrus peel extracts attenuated obesity and modulated gut microbiota in mice with high-fat diet-induced obesity. Food Funct. 2018. [CrossRef]

154. Ghasemi, K.; Ghasemi, Y.; Ebrahimzadeh, M.A. Antioxidant activity, phenol and flavonoid contents of 13 citrus species peels and tissues. Pak. J. Pharm. Sci. 2009, 22, 277-281.

155. Siegrist, M.; Sütterlin, B. Importance of perceived naturalness for acceptance of food additives and cultured meat. Appetite 2017, 113, 320-326. [CrossRef]

156. Vojdani, A.; Vojdani, C. Immune reactivity to food coloring. Altern. Ther. 2015, 21, 1-100.

157. Bézu, C.; Coutant, C.; Salengro, A.; Daraï, E.; Rouzier, R.; Uzan, S. Anaphylactic response to blue dye during sentinel lymph node biopsy. Surg. Oncol. 2011, 20, e55-e59. [CrossRef]

158. Rodriguez-Amaya, D.B. Natural Food Pigments and Colorants. In Bioactive Molecules in Food; Mérillon, J.-M., Ramawat, K.G., Eds.; Springer International Publishing: Cham, Switzerland, 2017; pp. 1-35.

159. Gordon, H.T.; Bauernfeind, J.C.; Furia, T.E. Carotenoids as food colorants. Crit. Rev. Food Sci. Nutr. 1983, 18, 59-97. [CrossRef]

160. Wissgott, U.; Bortlik, K. Prospects for new natural food colorants. Trends Food Sci. Technol. 1996, 7, $298-302$. [CrossRef]

161. Prata, E.R.B.A.; Oliveira, L.S. Fresh coffee husks as potential sources of anthocyanins. LWT-Food Sci. Technol. 2007, 40, 1555-1560. [CrossRef]

162. European Commission. Commission Regulation (EU) No 1129/2011 of 11 November 2011 amending Annex II to Regulation (EC) No 1333/2008 of the European Parliament and of the Council by Establishing a Union List of Food Additives Text with EEA Relevance; European Commission: Brussels, Belgium, 2011.

163. Gesundheitsamt, S.E.; Commission du Manuel Suisse des Denrées Alimentaires. Manuel Suisse des Denrées Alimentaires: Méthodes d'Analyse et d'Appréciation des Denrées Alimentaires et des Objets Usuels; Office Central Fédéral des Imprimés et du Matériel: Berne, Switzerland, 1969.

164. Carocho, M.; Barreiro, M.F.; Morales, P.; Ferreira, I.C. Adding molecules to food, pros and cons: A review on synthetic and natural food additives. Compr. Rev. Food Sci. Food Saf. 2014, 13, 377-399. [CrossRef]

165. Kodagoda, K.; Marapana, R. Utilization of fruit processing by-products for industrial applications: A review. Int. J. Food Sci. Nutr. 2017, 2, 24-30.

166. Joshi, R.V. Low calorie biscuits from banana peel pulp. J. Solid Waste Technol. Manag. 2007, 33, $142-147$.

167. Kanazawa, K.; Sakakibara, H. High Content of Dopamine, a Strong Antioxidant, in Cavendish Banana. J. Agric. Food Chem. 2000, 48, 844-848. [CrossRef]

168. Serna-Cock, L.; García-Gonzales, E.; Torres-León, C. Agro-industrial potential of the mango peel based on its nutritional and functional properties. Food Rev. Int. 2016, 32, 364-376. [CrossRef] 
169. Nobre, B.P.; Palavra, A.F.; Pessoa, F.L.; Mendes, R.L. Supercritical $\mathrm{CO}_{2}$ extraction of trans-lycopene from Portuguese tomato industrial waste. Food Chem. 2009, 116, 680-685. [CrossRef]

170. Wrolstad, R.E.; Culver, C.A. Alternatives to Those Artificial FD\&C Food Colorants. Annu. Rev. Food Sci. Technol. 2012, 3, 59-77. [CrossRef]

171. Saha, D.; Bhattacharya, S. Hydrocolloids as thickening and gelling agents in food: A critical review. J. Food Sci. Technol. 2010, 47, 587-597. [CrossRef]

172. Pressman, P.; Clemens, R.; Hayes, W.; Reddy, C. Food additive safety: A review of toxicologic and regulatory issues. Toxicol. Res. 2017, 1, 1-22. [CrossRef]

173. Mudgil, D.; Barak, S. Composition, properties and health benefits of indigestible carbohydrate polymers as dietary fiber: A review. Int. J. Biol. Macromol. 2013, 61, 1-6. [CrossRef]

174. Müller-Maatsch, J.; Bencivenni, M.; Caligiani, A.; Tedeschi, T.; Bruggeman, G.; Bosch, M.; Petrusan, J.; Van Droogenbroeck, B.; Elst, K.; Sforza, S. Pectin content and composition from different food waste streams. Food Chem. 2016, 201, 37-45. [CrossRef]

175. Jeong, H.-S.; Kim, H.-Y.; Ahn, S.H.; Oh, S.C.; Yang, I.; Choi, I.-G. Optimization of enzymatic hydrolysis conditions for extraction of pectin from rapeseed cake (Brassica napus L.) using commercial enzymes. Food Chem. 2014, 157, 332-338. [CrossRef]

176. Espírito-Santo, A.P.; Lagazzo, A.; Sousa, A.L.O.P.; Perego, P.; Converti, A.; Oliveira, M.N. Rheology, spontaneous whey separation, microstructure and sensorial characteristics of probiotic yoghurts enriched with passion fruit fiber. Food Res. Int. 2013, 50, 224-231. [CrossRef]

177. Yi, T.; Huang, X.; Pan, S.; Wang, L. Physicochemical and functional properties of micronized jincheng orange by-products (Citrus sinensis Osbeck) dietary fiber and its application as a fat replacer in yogurt. Int. J. Food Sci. Nutr. 2014, 65, 565-572. [CrossRef]

178. Zhang, T.; McCarthy, J.; Wang, G.; Liu, Y.; Guo, M. Physiochemical Properties, Microstructure, and Probiotic Survivability of Nonfat Goats' Milk Yogurt Using Heat-Treated Whey Protein Concentrate as Fat Replacer. J. Food Sci. 2015, 80, M788-M794. [CrossRef]

179. Saffon, M.; Richard, V.; Jiménez-Flores, R.; Gauthier, F.S.; Britten, M.; Pouliot, Y. Behavior of Heat-Denatured Whey: Buttermilk Protein Aggregates during the Yogurt-Making Process and Their Influence on Set-Type Yogurt Properties. Foods 2013, 2, 444-459. [CrossRef]

180. Sundar Raj, A.; Rubila, S.; Jayabalan, R.; Ranganathan, T. A review on pectin: Chemistry due to general properties of pectin and its pharmaceutical uses. Sci. Rep. 2012, 1, 550-551.

181. Crizel, T.D.M.; Araujo, R.R.D.; Rios, A.D.O.; Rech, R.; Flôres, S.H. Orange fiber as a novel fat replacer in lemon ice cream. J. Food Sci. Technol. 2014, 34, 332-340. [CrossRef]

182. M'hiri, N.; Ghali, R.; Nasr, I.B.; Boudhrioua, N. Effect of different drying processes on functional properties of industrial lemon byproduct. Process Saf. Environ. Prot. 2018, 116, 450-460. [CrossRef]

183. Beecher, G.R. Phytonutrients' Role in Metabolism: Effects on Resistance to Degenerative Processes. Nutr. Rev. 1999, 57, 3-6. [CrossRef]

184. Desmedt, A.; Jacobs, H. Soluble fiber. In Guide to Functional Foods; Young, J.E., Ed.; Leatherhead Publishing: Leatherhead, UK, 2001; pp. 112-132.

185. Santos, B.A.; Campagnol, P.C.B.; Pacheco, M.T.B.; Pollonio, M.A.R. Fructooligosaccharides as a fat replacer in fermented cooked sausages. Int. J. Food Sci. Technol. 2012, 47, 1183-1192. [CrossRef]

186. Brennan, C.S.; Tudorica, C.M. Carbohydrate-based fat replacers in the modification of the rheological, textural and sensory quality of yoghurt: Comparative study of the utilisation of barley beta-glucan, guar gum and inulin. Int. J. Food Sci. Technol. 2008, 43, 824-833. [CrossRef]

187. Radi, M.; Niakousari, M.; Amiri, S. Physicochemical, Textural and Sensory Properties of Low-Fat Yogurt Produced by Using Modified Wheat Starch as a Fat Replacer. J. Appl. Sci. Res. 2009, 9, 2194-2197.

188. Raftani, A.Z.; Mahmudi, M.; Alimi, M. Effect of maltodextrin as a fat replacer on the quality of non-fat yogurt. J. Food Res. 2013, 23, 133-142.

189. Crizel, T.D.M.; Jablonski, A.; Rios, A.D.O.; Rech, R.; Flôres, S.H. Dietary fiber from orange byproducts as a potential fat replacer. LWT-Food Sci. Technol. 2013, 53, 9-14. [CrossRef]

190. Dervisoglu, M.; Yazici, F. Note. The Effect of Citrus Fibre on the Physical, Chemical and Sensory Properties of Ice Cream. Int. J. Food Sci. Technol. 2006, 12, 159-164. [CrossRef] 
191. Guerrero García Ortega, M.; Riballo Ruiz-Roso, M.; Crespo Bermejo, A. Obtaining enriched fried tomato sauce using tomato byproducts. In Proceedings of the XIV International Symposium on Processing Tomato 1159; ISHS: Leuven, Belgium, 2017; pp. 167-174.

192. Nussinovitch, A.; Hirashima, M. More Cooking Innovations: Novel Hydrocolloids for Special Dishes; CRC Press: Boca Raton, FL, USA, 2018.

193. Lee, S.; Inglett, G.E.; Palmquist, D.; Warner, K. Flavor and texture attributes of foods containing $\beta$-glucan-rich hydrocolloids from oats. LWT-Food Sci. Technol. 2009, 42, 350-357. [CrossRef]

194. Domagała, J.; Sady, M.; Grega, T.; Bonczar, G. Rheological properties and texture of yoghurts when oat-maltodextrin is used as a fat substitute. Int. J. Food Prop. 2006, 9, 1-11. [CrossRef]

195. Ahmad, A.; Munir, B.; Abrar, M.; Bashir, S.; Adnan, M.; Tabassum, T. Perspective of $\beta$-glucan as functional ingredient for food industry. J. Nutr. Food Sci. 2012, 2, 133. [CrossRef]

196. Campos-Vega, R.; Nieto-Figueroa, K.H.; Oomah, B.D. Cocoa (Theobroma cacao L.) pod husk: Renewable source of bioactive compounds. Trends Food Sci. Technol. 2018, 81, 172-184. [CrossRef]

197. Ralla, T.; Salminen, H.; Edelmann, M.; Dawid, C.; Hofmann, T.; Weiss, J. Oat bran extract (Avena sativa L.) from food by-product streams as new natural emulsifier. Food Hydrocoll. 2018, 81, 253-262. [CrossRef]

198. Everett, D.W.; McLeod, R.E. Interactions of polysaccharide stabilisers with casein aggregates in stirred skim-milk yoghurt. Int. Dairy J. 2005, 15, 1175-1183. [CrossRef]

199. Aryana, K.; Plauche, S.; Rao, R.; McGrew, P.; Shah, N. Fat-free plain yogurt manufactured with inulins of various chain lengths and Lactobacillus acidophilus. J. Food Sci. 2007, 72, M79-M84. [CrossRef]

200. Sahan, N.; Yasar, K.; Hayaloglu, A.A. Physical, chemical and flavour quality of non-fat yogurt as affected by a $\beta$-glucan hydrocolloidal composite during storage. Food Hydrocoll. 2008, 22, 1291-1297. [CrossRef]

201. Mistry, V.V.; Hassan, H.N. Manufacture of Nonfat Yogurt from a High Milk Protein Powder. J. Dairy Sci. 1992, 75, 947-957. [CrossRef]

202. Guzmán-González, M.; Morais, F.; Ramos, M.; Amigo, L. Influence of skimmed milk concentrate replacement by dry dairy products in a low fat set-type yoghurt model system. I: Use of whey protein concentrates, milk protein concentrates and skimmed milk powder. J. Sci. Food Agric. 1999, 79, 1117-1122. [CrossRef]

203. Lobato-Calleros, C.; Martínez-Torrijos, O.; Sandoval-Castilla, O.; Pérez-Orozco, J.P.; Vernon-Carter, E.J. Flow and creep compliance properties of reduced-fat yoghurts containing protein-based fat replacers. Int. Dairy J. 2004, 14, 777-782. [CrossRef]

204. Sandoval-Castilla, O.; Lobato-Calleros, C.; Aguirre-Mandujano, E.; Vernon-Carter, E.J. Microstructure and texture of yogurt as influenced by fat replacers. Int. Dairy J. 2004, 14, 151-159. [CrossRef]

205. Bryant, C.M.; McClements, D.J. Molecular basis of protein functionality with special consideration of cold-set gels derived from heat-denatured whey. Trends Food Sci. Technol. 1998, 9, 143-151. [CrossRef]

206. Wang, W.; Bao, Y.; Hendricks, G.M.; Guo, M. Consistency, microstructure and probiotic survivability of goats' milk yoghurt using polymerized whey protein as a co-thickening agent. Int. Dairy J. 2012, 24, 113-119. [CrossRef]

207. Lin, Y.; Kelly, A.L.; O'Mahony, J.A.; Guinee, T.P. Fortification of milk protein content with different dairy protein powders alters its compositional, rennet gelation, heat stability and ethanol stability characteristics. Int. Dairy J. 2016, 61, 220-227. [CrossRef]

208. Bruzantin, F.; Daniel, J.; da Silva, P.; Spoto, M. Physicochemical and sensory characteristics of fat-free goat milk yogurt with added stabilizers and skim milk powder fortification. J. Dairy Sci. 2016, 99, 3316-3324. [CrossRef]

209. Jiménez-Flores, R.; Brisson, G. The milk fat globule membrane as an ingredient: Why, how, when? Dairy Sci. Technol. 2008, 88, 5-18. [CrossRef]

210. Singh, $\mathrm{H}$. The milk fat globule membrane-A biophysical system for food applications. Curr. Opin. Colloid Interface Sci. 2006, 11, 154-163. [CrossRef]

211. Mistry, V.V.; Metzger, L.E.; Maubois, J.L. Use of Ultrafiltered Sweet Buttermilk in the Manufacture of Reduced Fat Cheddar Cheese ${ }^{1}$. J. Dairy Sci. 1996, 79, 1137-1145. [CrossRef]

212. Turcot, S.; St-Gelais, D.; Turgeon, S.L. Affinage de fromages allégés de type Cheddar fabriqués à partir de laits enrichis en phospholipides. Le Lait 2002, 82, 209-223. [CrossRef]

213. Kinsella, J. Relationships between structure and functional properties of food proteins. Food Proteins 1982, 1, 51-103. 
214. Yavuz, H.Z.; Ozcan, M.M.; Lemiasheuski, V.K. The Effect of Some Chemical Additives on the Foaming Performance of the Pasteurized Liquid Egg White. J. Nutr. Metab. 2018, 5, 1054.

215. Mita, T.; Ishida, E.; Matsumoto, H. Physicochemical studies on wheat protein foams. II. Relationship between bubble size and stability of foams prepared with gluten and gluten components. J. Colloid Interface Sci. 1978, 64, 143-153. [CrossRef]

216. Kralova, I.; Sjöblom, J. Surfactants Used in Food Industry: A Review. J. Dispers. Sci. Technol. 2009, 30, 1363-1383. [CrossRef]

217. Johnson, T.M.; Zabik, M.E. Ultrastructural examination of egg albumen protein foams. J. Food Sci. 1981, 46, 1237-1240. [CrossRef]

218. Karayannakidis, P.D.; Zotos, A. Fish processing by-products as a potential source of gelatin: A review. J. Aquat. Food Prod. Technol. 2016, 25, 65-92. [CrossRef]

219. Muzaifa, M.; Safriani, N.; Zakaria, F. Production of protein hydrolysates from fish by-product prepared by enzymatic hydrolysis. Aquac. Aquar. Conserv. Legis. 2012, 5, 36-39.

220. Kotlar, C.E.; Ponce, A.G.; Roura, S.I. Improvement of functional and antimicrobial properties of brewery byproduct hydrolysed enzymatically. LWT-Food Sci. Technol. 2013, 50, 378-385. [CrossRef]

221. Hsieh, Y.; Ofori, J.A. Food-grade proteins from animal by-products. Their usage and detection methods. In Handbook of Analysis of Edible Animal by-Products; CRC Press: Boca Raton, FL, USA, 2011; pp. 3-11.

222. Kang, I.S.; Lanier, T.C. Bovine Plasma Protein Functions in Surimi Gelation Compared with Cysteine Protease Inhibitors. J. Food Sci. 1999, 64, 842-846. [CrossRef]

223. Yousif, A.M.; Cranston, P.; Deeth, H.C. Incorporation of bovine dry blood plasma into biscuit flour for the production of pasta. LWT-Food Sci. Technol. 2003, 36, 295-302. [CrossRef]

224. Del Hoyo, P.; Rendueles, M.; Díaz, M. Effect of processing on functional properties of animal blood plasma. Meat Sci. 2008, 78, 522-528. [CrossRef]

225. Whitehurst, R.J. Emulsifiers in Food Technology; John Wiley \& Sons: New York, NY, USA, 2008.

226. Ozturk, B.; McClements, D.J. Progress in natural emulsifiers for utilization in food emulsions. Curr. Opin. Food Sci. 2016, 7, 1-6. [CrossRef]

227. Imafidon, G.I.; Farkye, N.Y.; Spanier, A.M. Isolation, purification, and alteration of some functional groups of major milk proteins: A review. Crit. Rev. Food Sci. Nutr. 1997, 37, 663-689. [CrossRef]

228. Toldrà, M.; Lynch, S.A.; Couture, R.; Álvarez, C. Blood Proteins as Functional Ingredients. In Sustainable Meat Production and Processing; Elsevier: Amsterdam, The Netherlands, 2019; pp. 85-101.

229. Leoci, R. Animal by-Products (ABPs): Origins, Uses, and European Regulations; Universitas Studiorum S.r.l.: Mantova, Italy, 2014. 